\title{
PLASMA SPRAYED Ni-Al COATINGS FOR SAFE ENDING HEAT EXCHANGER TUBES
}

\author{
M.L. Allan \\ Energy Efficiency and Conservation Division \\ Department of Applied Science \\ Brookhaven National Laboratory \\ Upton, New York 11973 \\ D. Otterson and C.C. Berndt \\ Department of Materials Science and Engineering \\ State University of New York at Stony Brook \\ Stony Brook, New York 11794
}

NOVEMBER 1998

This report issued by Raymond LaSala (Program Manager, DOE Geothermal Technology Division) was performed under the auspices of the U.S. Department of Energy, Washington, D.C. under Contract No. DE-AC02-98CH10886. 


\section{DISCLAIMER}

This report was prepared as an account of work sponsored by an agency of the United States Government. Neither the United States Government nor any agency thereof, nor any of their employees, make any warranty, express or implied, or assumes any legal liability or responsibility for the accuracy, completeness, or usefulness of any information, apparatus, product, or process disclosed, or represents that its use would not infringe privately owned rights. Reference herein to any specific commercial product, process, or service by trade name, trademark, manufacturer, or otherwise does not necessarily constitute or imply its endorsement, recommendation, or favoring by the United States Government or any agency thereof. The views and opinions of authors expressed herein do not necessarily state or reflect those of the United States Government or any agency thereof. 


\section{DISCLAIMER}

\section{Portions of this document may be illegible in electronic image products. Images are produced from the best available original document.}




\section{TABLE OF CONTENTS}

\section{Page}

Summary $\ldots \ldots \ldots \ldots \ldots \ldots \ldots \ldots \ldots \ldots \ldots \ldots \ldots \ldots \ldots \ldots \ldots \ldots \ldots \ldots \ldots \ldots$

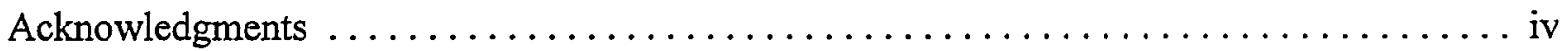

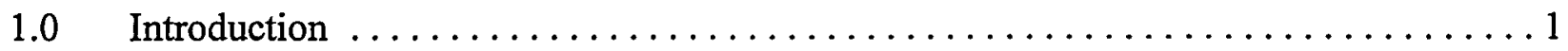

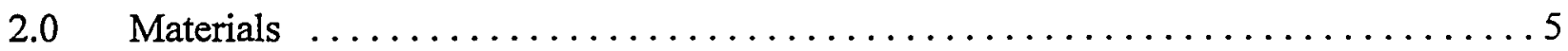

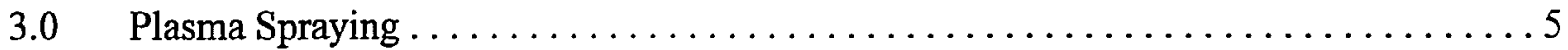

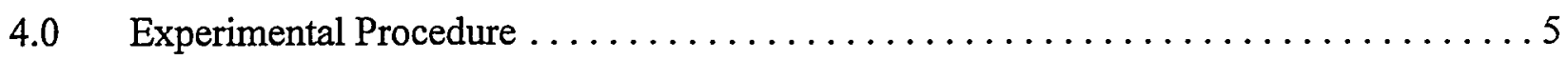

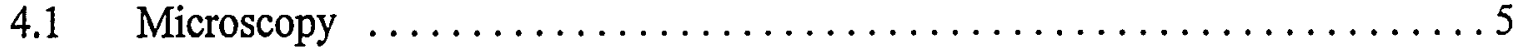

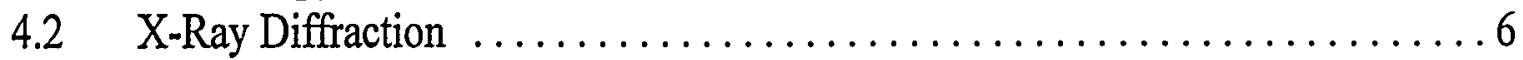

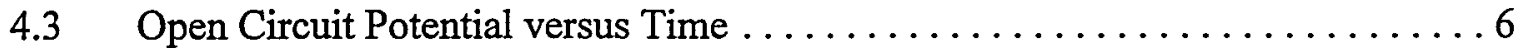

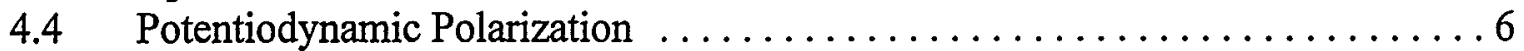

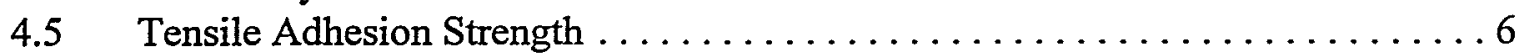

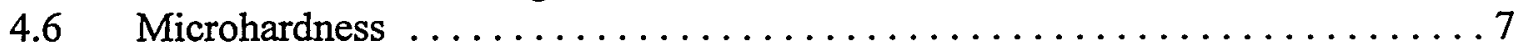

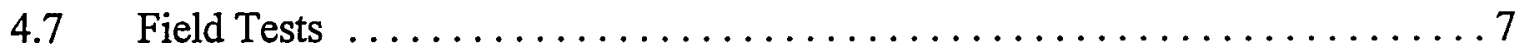

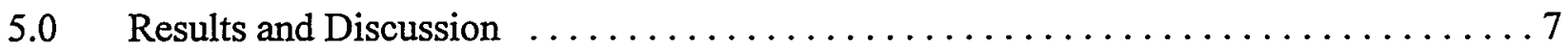

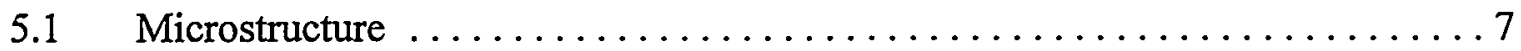

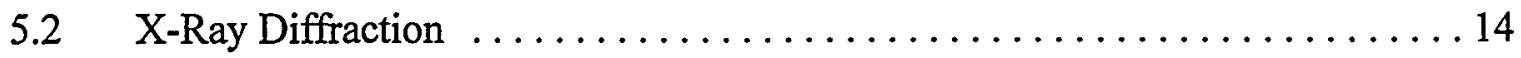

5.3 Open Circuit Potential . . . . . . . . . . . . . . . . . . . 20

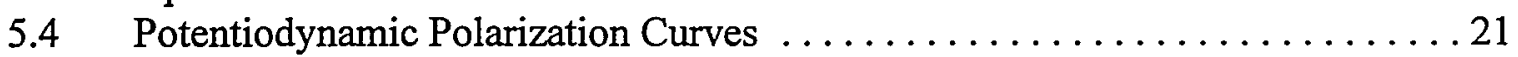

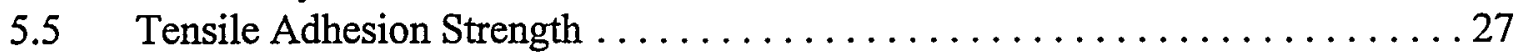

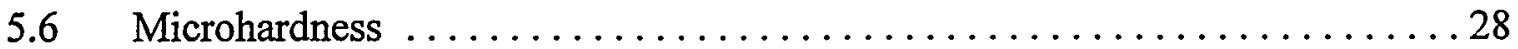

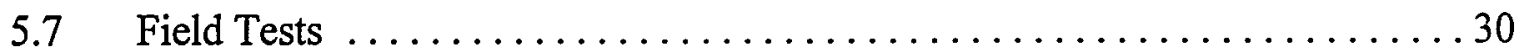

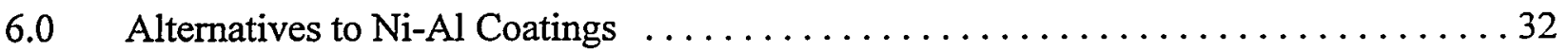

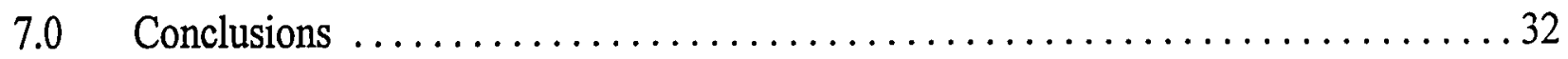

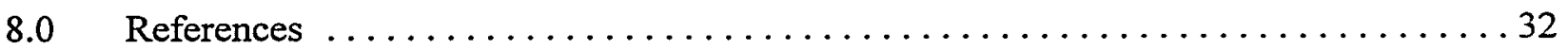




\section{SUMMARY}

Brookhaven National Laboratory (BNL) has developed thermally conductive composite liners for corrosion and scale protection in heat exchanger tubes exposed to geothermal brine. The liners cannot withstand roller expansion to connect the tubes to the tubesheet. It is not possible to line the ends of the tubes with the same material after roller expansion due to the nature of the current liner application process. It was requested that $\mathrm{BNL}$ evaluate plasma sprayed $\mathrm{Ni}-\mathrm{Al}$ coatings for safe ending heat exchanger tubes exposed to geothermal brine. The tubes of interest had an internal diameter of 0.875 inches. It is not typical to thermal spray small diameter components or use such small standoff distances. In this project a nozzle extension was developed by Zatorski Coating Company to spray the tube ends as well as flat coupons for testing.

Four different Ni-Al coatings were investigated. One of these was a ductilized Ni-AlB material developed at Oak Ridge National Laboratory. The coatings were examined by optical and scanning electron microscopy. In addition, the coatings were analysed by X-ray diffraction and subjected to corrosion, tensile adhesion, microhardness and field tests in a volcanic pool in New Zealand.

It was determined that the $\mathrm{Ni}-\mathrm{Al}$ coatings could be applied to a depth of two inches on the tube ends. When sprayed on flat coupons the coatings exhibited relatively high adhesion strength and microhardness. Polarization curves showed that the coating performance was variable. Measured corrosion potentials indicated that the $\mathrm{Ni}$ - $\mathrm{Al}$ coatings are active towards steel coated with thermally conductive polymers, thereby suggesting preferential corrosion. Corrosion also occurred on the coated coupons tested in the volcanic pool. This may have been exacerbated by the difficulty in applying a uniform coating to the coupon edges. The Ni-Al coatings applied to the tubes had significant porosity and did not provide adequate corrosion protection. This is associated with the short standoff distance and is not a reflection of the normal quality of plasma sprayed coatings. Even if coating porosity could be reduced, the coupling of an alloy coating to a polymer-based barrier coating in the same electrolyte is not recommended. Therefore, polymer coatings that can be field applied to the tube ends after roller expansion should be sought. 


\section{ACKNOWLEDGMENTS}

This work was funded by the U.S. Department of Energy/Office of Geothermal Technologies. Thanks are due to Mr. Ray LaSala for supporting this activity. The authors also thank Mr. Dominic Vasquez, Dr. Eugil Lee and Dr. Carlos Lima for preparing specimens and performing the tensile adhesion tests. 


\subsection{Introduction}

Shell and tube heat exchangers are used in binary cycle geothermal power plants to generate electricity from low to moderate temperature resources. Geothermal brine is used to vaporize a hydrocarbon working fluid which is then expanded through a turbine. Due to the corrosivity of brine heat exchangers are frequently constructed from titanium alloys or stainless steel. Hence, heat exchangers represent a significant proportion of binary plant cost. A remaining operational and maintenance problem is excessive internal scaling of the heat exchanger tubes which decreases heat transfer rate and necessitates routine shutdowns for cleaning.

Capital costs could be reduced if heat exchangers were constructed from cheaper, yet durable, materials. One possibility is to use carbon steel heat exchanger tubes lined with thermally conductive, protective coatings. If these liners can also be designed to impart scale resistance then maintenance costs could be decreased.

Brookhaven National Laboratory (BNL) has developed several polymer-based thermally conductive liners for the fluid side of carbon steel heat exchanger tubes to reduce corrosion and fouling. These liners are currently being evaluated in collaboration with NREL and CalEnergy. One liner system is based on styrene trimethylolpropane trimethacrylate (ST/TMPTMA) and the other on polyphenylene sulfide (PPS). A detail not yet resolved is attachment of the lined tube to the tubesheet. The composite liners will not withstand the stresses associated with roller expansion or heat induced by welding. Therefore, the ends of the tubes require a system that is resistant to mechanical or thermal damage. It is not possible to coat the tube ends with the thermally conductive composites after roller expansion due to the application and processing requirements of these materials. The tubes that are being field tested have a stub of AL- $6 \mathrm{XN}$ alloy welded onto the ends prior to lining. It is this stub that is subsequently roller expanded.

Joining two dissimilar materials runs the risk of galvanic corrosion unless both are electrically isolated from the electrolyte, in this case brine, by a continuous barrier coating. AL-6XN stubs can be expected to be cathodic towards carbon steel. Coating the anode only does not solve the problem since any coating defects will give rise to localized corrosion. Hence, a better system is required to prevent galvanic corrosion of the heat exchanger tubes.

The objectives of this project were to demonstrate and evaluate plasma spray nickel aluminum coatings suitable for production-scale safe-ending of heat exchanger tubes. Nickel aluminum was requested by the Program Manager, Mr. Ray LaSala. In addition to nickel aluminum, there are other materials that could possibly be appropriate for the application. These might include Inconel 625 or other $\mathrm{NiCr}$-base alloys or polymers with required high temperature durability in geothermal brines. The optimal solution would be to have the entire carbon steel tube lined with the same material.

Roller expansion is the most common method for attaching tubes to tubesheets and was the only joining method considered in this project. Further details of the method are given by Singh and 
Soler (1984). The tube is plastically deformed to form a leakproof joint. The quality of bond produced by roller expansion depends on the stress-strain characteristics of the tube and tubesheet materials, number of rollers, mandrel speed, finish of surfaces to be joined and tubesheet ligament size. The length of the roll is typically $2 "$.

In order to avoid any potential damage to the thermally conductive composite liner by roller expansion, it is necessary to leave the last 2" bare. The bare ends must be coated either before or after roller expansion. Logically, it is preferable to coat the ends after joining to the tubesheet to minimize the risk of harming the coating.

Thermal spray refers to the process in which a feedstock material is heated and projected onto a substrate where it solidifies. The molten particles flatten when they impact the substrate and form a lamellar microstructure. The coating thus consists of lamellar particles, oxides and pores. There are several different thermal spray processes and these can be broadly categorized as flame, arc, plasma, and high velocity oxygen fuel (HVOF). The coating properties are strongly dependent on the process used. Plasma and HVOF coatings have lower porosity than flame or arc sprayed coatings and are of greater interest for corrosion protection in severe environments. This project was limited to evaluation of plasma sprayed coatings.

The internal diameter of the heat exchanger tubes currently being lined at BNL is $0.875^{\prime \prime}$. Thermal spraying with conventional equipment can typically coat the inner diameter of tubes to an aspect ratio of two. This involves non-ideal spray angles which subsequently results in a lower quality coating. A possible means of plasma spraying the internal surface of the heat exchanger tube ends is to use a specialized plasma gun designed for small internal diameters. Sulzer Metco had a gun (F3) that can spray internal areas with a diameter of 1.2". This gun was used for spraying turbine engine fan disk slots. However, it is no longer in commercial production. Other thermal spray equipment manufacturers were contacted but nothing suitable for the small tubes was located. An alternative is to add a nozzle extension to a standard plasma spraying gun to coat small internal areas. Such a system could possibly be used to coat the ends of heat exchanger tubes, particularly if the coating could be applied in the field after roller expansion.

Thermal sprayed nickel aluminum is widely used as a bond coat between the substrate and top coating. The purpose of the bond coat is to enhance adhesion and integrity of thermal sprayed systems. Ni-Al coatings also exhibit oxidation and abrasion resistance at high temperatures. They are not commonly used for corrosion protection in aqueous environments and one supplier's technical bulletin does not recommend its use in such conditions. The properties of coatings produced from different composition $\mathrm{Ni}-\mathrm{Al}$ wire and powders and the effects of different spraying techniques have been studied extensively. Examples of such research include McPherson and Cheang (1989), Sampath et al. (1987; 1990), Khor and Loh (1994), Geibel et al. (1996), Yiru et al. (1986), Kozerski (1986), Knotek et al. (1980), and Svantesson and Wigren (1992).

The phases and microstructure formed when spraying $\mathrm{Ni}-\mathrm{Al}$ depend on the feedstock, process and parameters used. Ni-Al is available in wire or powder form. For this project only powders were 
of interest. The typical powder compositions available are Ni-4.5Al, Ni-5Al, Ni-18Al and Ni-20Al. The powders can be clad (composite) or pre-alloyed. $\mathrm{Ni}-4.5 \mathrm{Al}$ and $\mathrm{Ni}-5 \mathrm{Al}$ clad powders consist of a Ni core and an outer shell of Al whereas Ni-20Al is Ni clad on Al. Pre-alloyed powders can be gas or water atomized. $\mathrm{Ni}$ and $\mathrm{Al}$ powders can also be blended or sprayed separately. This form of reactive spraying has been used to produce nickel aluminide coatings by Deevi et al. (1997).

Knotek et al. (1980) flame sprayed a number of different powders. Atomized Ni-5Al was found to produce $\alpha-\mathrm{Ni}, \mathrm{NiO}$ and $\gamma-\mathrm{Al}_{2} \mathrm{O}_{3}$. Clad $\mathrm{Ni}-20 \mathrm{Al}$ powders produced the same phases in addition to intermetallic $\mathrm{Ni}_{3} \mathrm{Al}$ and traces of NiAl. Kozerski (1986) reviewed literature on thermal sprayed $\mathrm{Ni}-\mathrm{Al}$ and noted that the phases formed were variable. The effect of $\mathrm{P}$ on oxidation of $\mathrm{Ni}$ during plasma spraying of Ni-Al was studied by Kozerski (1986). Ni-30Al coatings were found to contain numerous oxides $\left(\mathrm{NiO}, \mathrm{NiAl}_{2} \mathrm{O}_{4}\right.$ and $\left.\gamma-\mathrm{Al}_{2} \mathrm{O}_{3}\right)$. Addition of $4 \% \mathrm{P}$ removed $\mathrm{NiO}$ and $\mathrm{NiAl}_{2} \mathrm{O}_{4}$.

McPherson and Cheang (1989) plasma sprayed clad Ni-4.5Al and pre-alloyed Ni-5Al and compared the microstructure, oxide content and tensile adhesion strength for different standoff distances. The proportion of $\gamma-\mathrm{Al}_{2} \mathrm{O}_{3}$ was higher in the coatings prepared from pre-alloyed Ni-5Al while the proportion of $\mathrm{NiO}$ was lower. The oxide content increased with increasing standoff distance. Coatings from pre-alloyed powders had lower porosity. For both types of coatings the porosity increased with standoff distance. The tensile adhesion strength was found to be higher for the pre-alloyed Ni-Al.

Atmospheric and vacuum plasma spraying of different $\mathrm{Ni}-\mathrm{Al}$ powders was performed by Sampath et al. (1987). The powders studied were clad Ni-5Al, clad Ni-20Al, gas atomized Ni-5Al and water atomized Ni-5Al. The phases formed in the coatings varied with the feedstock material and spraying process. Nickel aluminide phases were only formed in the clad materials when they were vacuum plasma sprayed. As expected, more oxides were produced during the atmospheric plasma spraying process. The gas atomized Ni-5Al formed $\alpha-\mathrm{Ni}$ when either sprayed in air or vacuum. Some $\mathrm{Al}_{2} \mathrm{O}_{3}$ stringers were detected in the $\alpha-\mathrm{Ni}$ for the atmospheric sprayed coating. Similar results were found for the water atomized Ni-5Al coatings except that oxidation was less.

Svantesson and Wigren (1992) examined the phases formed, corrosion resistance, hardness and tensile adhesion strength of plasma sprayed coatings produced from different $\mathrm{Ni}-5 \mathrm{Al}$ feedstock powders. Clad powders produced coatings with free $\mathrm{Al}$ in $\alpha-\mathrm{Ni}, \mathrm{NiO}$ and $\mathrm{Al}_{2} \mathrm{O}_{3}$. The coatings from atomized (pre-alloyed) powders consisted of $\mathrm{Al}_{2} \mathrm{O}_{3}$ in $\alpha$-Ni. Sintered powder produced $\mathrm{Ni}_{3} \mathrm{Al}, \mathrm{NiO}$ and $\mathrm{Al}_{2} \mathrm{O}_{3}$ in $\alpha-\mathrm{Ni}$. $\mathrm{Ni}_{3} \mathrm{Al}$ was already present in the starting material. Salt spray tests in accordance with ASTM B117 were performed and the coatings were found to be resistant to attack after 100 hours of testing. The coatings underwent degradation when exposed to saturated $\mathrm{SO}_{2}$ for 200 hours. The highest adhesion strength was obtained for a gas atomized powder that contained $0.2 \% \mathrm{~B}$. Addition of $B$ is of interest for improving ductility and this is discussed further below. The same coating also displayed the highest microhardness.

Several concerns exist for the successful use of $\mathrm{Ni}-\mathrm{Al}$ coatings for safe ending heat exchanger 
tubes. These include corrosion and scaling resistance, compatibility with the thermally conductive composite liner, presence of pores and oxides, and ductility. Like other intermetallics, nickel aluminides are hard and brittle. Hence, the presence of nickel aluminide phases in Ni-Al coatings will decrease ductility. This is a strong limitation if the coated end of the tube is to be roller expanded. Low ductility, combined with pores that can act as stress concentrators and oxides that provide paths for crack propagation, obviously increases the risk of coating damage during expansion. This problem was discussed with several thermal spray companies and it was unanimously agreed that such coatings should not be subjected to deliberate plastic deformation. Furthermore, flame sprayed Ni-Al coatings that were roller expanded as part of a collaborative field trial with NREL and CalEnergy reportedly flaked off. The best approach if Ni-Al coatings are to be used is to spray after roller expansion. Other alternatives include post treatment or addition of alloying elements to improve ductility. However, these may not have the desired effectiveness.

Annealing of the thermal sprayed coating is a potential means of increasing ductility but is not practical for the lined heat exchanger tubes. Boron has been found to increase the ductility of $\mathrm{Ni}_{3} \mathrm{Al}$ (Liu et al., 1985) but not that of NiAl (George and Liu, 1990). NiAl-B has been vacuum plasma sprayed by Chen et al., (1993). Reinshagen and Sikka (1991) sprayed Ni-Al-B using HVOF and plasma processes. The alloy sprayed is designated as IC-50 and its composition is $11.3 \% \mathrm{Al}$, $0.6 \% \mathrm{Zr}, 0.02 \% \mathrm{~B}, \mathrm{Ni}$ balance.

It is common to reduce or seal the porosity of thermal sprayed coatings particularly if they are intended for corrosion protection. Khor and Loh (1994) used hot isostatic pressing to densify plasma sprayed Ni-5Al and Ni-20Al. Reduction in porosity up to $89 \%$ was achieved with a concomitant increase in hardness. Various commercial materials for sealing coatings exist. These range from simple waxes to numerous organics and inorganics (e.g., epoxies, phenolics, vinyl esters, polyesters, silicone resins, methacrylates, silicates and polyurethanes). Such sealants can be brushed or sprayed onto the thermal sprayed coating. Sealing by sol-gel ceramic precursors has also been used to reduce porosity and improve corrosion resistance (e.g., Karthikeyan et al., 1996; John and Troczynski, 1996; Moriya et al., 1994). This process involves heat treatment up to several hundred degrees. For the heat exchanger tube ends a suitable sealant should preferably cure in air at room temperature, exhibit good penetration without the need for a vacuum and have durability in geothermal brines.

This project explored several different $\mathrm{Ni}-\mathrm{Al}$ materials, including a Ni-Al-B alloy with expected increased ductility. Other materials that may be suitable were not investigated as Ni-Al was the stipulated material. However, when an opportunity arose to test some coatings in a volcanic pool in New Zealand three other materials were used to provide a comparison with Ni-Al. A means of plasma spraying the ends of tubes through use of an extension to a plasma gun was developed. The coatings were characterized for microstructure, phase composition, electrochemical behaviour, hardness and tensile adhesion strength. 


\subsection{Materials}

The Ni-Al materials tested were Metco 450 (Ni-4.5 Al, clad), Metco 480 (Ni-5Al, prealloyed, gas atomized), Ametek IC-50 (Ni-11Al-0.02B) and X-form 205 (Ni-40Al, reaction synthesized). The coatings used in the New Zealand tests were Ni-5Al (pre-alloyed), $\mathrm{NiCr}-\mathrm{Cr}_{3} \mathrm{C}_{2}$, NiCoCrAlY and ethylene methacrylic acid.

\subsection{Plasma Spraying}

The plasma spraying was performed by Zatorski Coating Co. A nozzle extension system was developed to permit spraying the internal diameter of the HX tube ends using a standard arc-plasma gun. In order to prevent thermal damage of the composite liners, cooling jets were added. The same system was used to spray flat coupons and tensile adhesion test specimens. Figure 1 is a photograph of the gun used.

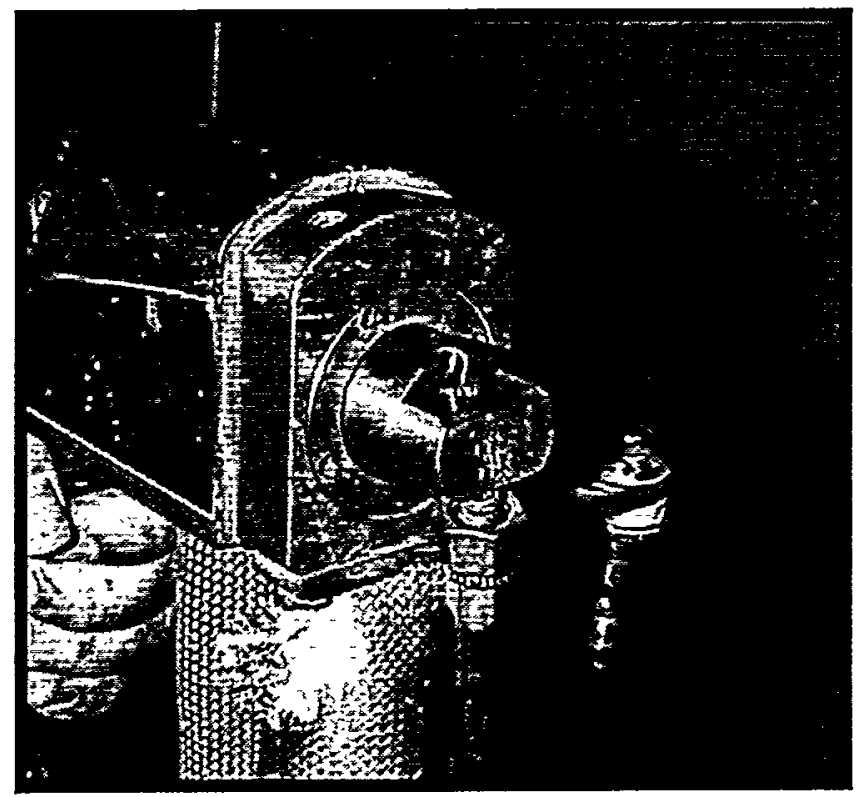

Figure 1. Plasma spraying gun used to apply coatings on tube ends.

\subsection{Experimental Procedure}

\subsection{Microscopy}

The microstructure of the coatings was analyzed using optical and scanning electron microscopy (SEM). Sprayed specimens were cross-sectioned and viewed at magnifications of $25 \mathrm{x}$, $50 \mathrm{x}$ and $100 \mathrm{x}$. The surfaces of the coatings were examined by SEM to gain an indication of surface 
melting. Compositional analysis was performed using X-ray photoelectron spectroscopy (XPS). The XPS analysis was done by rastering the electron beam across the surface in a representative area as counts were taken by the detector attached to the SEM.

\subsection{X-Ray Diffraction}

$\mathrm{X}$-ray diffraction was used to determine the components and phases present in the coatings. Copper $\mathrm{k}-\alpha$ radiation was used at $40 \mathrm{kV}$ and $30 \mathrm{~mA}$ to generate the spectra at $2 \theta$ angles between $20^{\circ}$ and $80^{\circ}$. The peaks in the spectra were then normalized and compared to the relative intensities and positions of peaks for known $\mathrm{Ni}$ and $\mathrm{Al}$ compounds.

\subsection{Open Circuit Potential versus Time}

The open circuit potentials of Metco 450 and X-form $205 \mathrm{Ni}$-Al coatings on flat mild steel substrates and bare steel exposed to synthetic geothermal brine at room temperature were monitored. The Metco 450 was both flame and plasma sprayed for comparison. A section of $50 \mathrm{~mm}$ diameter PVC pipe was glued onto the surface of flat coupons that were $75 \mathrm{~mm} \times 75 \mathrm{~mm}$. The pipe was filled with brine with a composition of $58,000 \mathrm{ppm} \mathrm{NaCl}, 25,000 \mathrm{ppm} \mathrm{CaCl}_{2}, 15,000 \mathrm{ppm} \mathrm{KCl}, 1000 \mathrm{ppm}$ $\mathrm{FeCl}_{2}, 930 \mathrm{ppm} \mathrm{MnCl}_{2}, 430 \mathrm{ppm} \mathrm{SrCl}_{2}, 410 \mathrm{ppm} \mathrm{LiCl}, 370 \mathrm{ppm} \mathrm{ZnCl}, 330 \mathrm{ppm} \mathrm{H}_{3} \mathrm{BO}_{3}$ and 130 $\mathrm{ppm} \mathrm{BaCl}_{2}$. The $\mathrm{pH}$ of the brine was 4.15. Open circuit potential was measured using a saturated calomel electrode. The potentials were monitored for 48 days.

Potentials on tubes sprayed with Metco 480 and exposed to brine were also monitored. These tubes were sliced longitudinally after spraying and the ends were capped . In addition, potentials on tubes coated with PPS and ST/TMPTMA were measured for comparison.

\subsection{Potentiodynamic Polarization}

Potentiodynamic polarization curves for the different $\mathrm{Ni}-\mathrm{Al}$ coatings and bare steel in brine were obtained using an EG\&G Model 173 potentiostat in conjunction with a universal programmer. The brine composition was the same as that above. The open circuit potential was measured with a saturated calomel electrode and the initial applied potential set at a value approximately $200 \mathrm{mV}$ more negative. The scan rate was $1 \mathrm{mV} / \mathrm{s}$. The polarization experiments were terminated when current was observed to increase sharply. A minimum of two scans were performed on specimens cut from the same original coupon.

\subsection{Tensile Adhesion Strength}

The bond strength of the coatings to steel substrates was measured in accordance with ASTM C 633. Coatings were sprayed onto $25 \mathrm{~mm}$ diameter grit blasted stubs. Each coated stub was glued to an uncoated stub using epoxy adhesive film. A hydraulic Instron testing machine was used to measure the tensile adhesion strength. Twelve specimens per coating were tested. 


\subsection{Microhardness}

The Vickers microhardness of the different coatings was compared. A diamond shaped indenter was used to test the hardness of the coating cross section. The load was $500 \mathrm{~g}$ for $15 \mathrm{~s}$. Twenty measurements per coating were made.

\section{7 $\quad$ Field Tests}

Plasma sprayed Ni-5Al, $\mathrm{NiCr}-\mathrm{Cr}_{3} \mathrm{C}_{2}$ and $\mathrm{NiCoCrAlY}$ coatings on steel substrates were sent to New Zealand for testing in a hot volcanic pool. The coupons were $28 \times 51 \times 3.2 \mathrm{~mm}$. The coatings were 300 to $500 \mu \mathrm{m}$ thick on the faces. It was difficult to produce an even coating on the coupon edges. Thermal sprayed ethylene methacrylic acid coatings were also tested for comparison. The testing was conducted by Mr. Keith Lichti of Materials Performance Technologies, Industrial Research Limited. The test site was Pool \#13A on White Island. The liquid in the pool had a pH of 1.45 to 1.59 and 1576 to $1742 \mathrm{ppm} \mathrm{Cl}^{-}$and 3360 to $4140 \mathrm{ppm} \mathrm{SO}_{4}{ }^{2-}$, depending on when sampled. The temperature was $99^{\circ} \mathrm{C}$ and the test duration was 43 days. Previous corrosion tests in this and other pools on White Island are described by Lichti et al. $(1997,1998)$.

\subsection{Results and Discussion}

\section{1 $\quad$ Microstructure}

Figures 2 to 10 show optical and SEM micrographs of coating cross sections and surface features from flat coupons. Cross sections of coatings sprayed on tubes are depicted in Figures 11 to 14 .

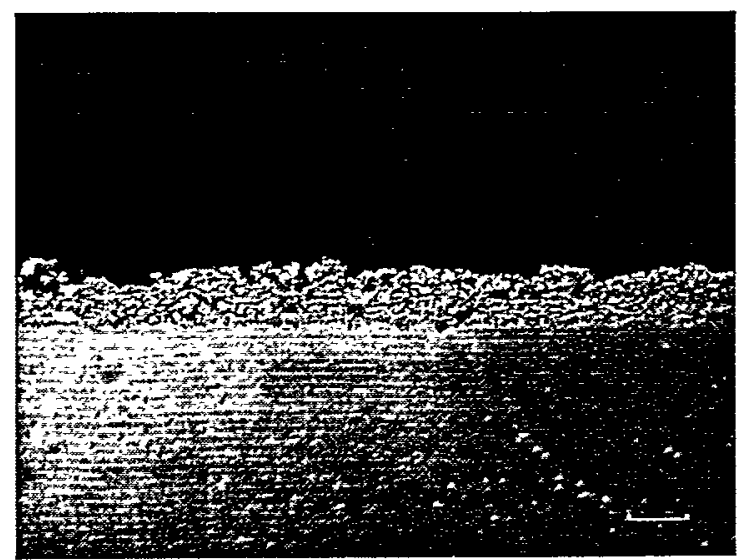

Figure 2. Cross section of flame sprayed Metco 450 at $50 \mathrm{X}$ magnification. 

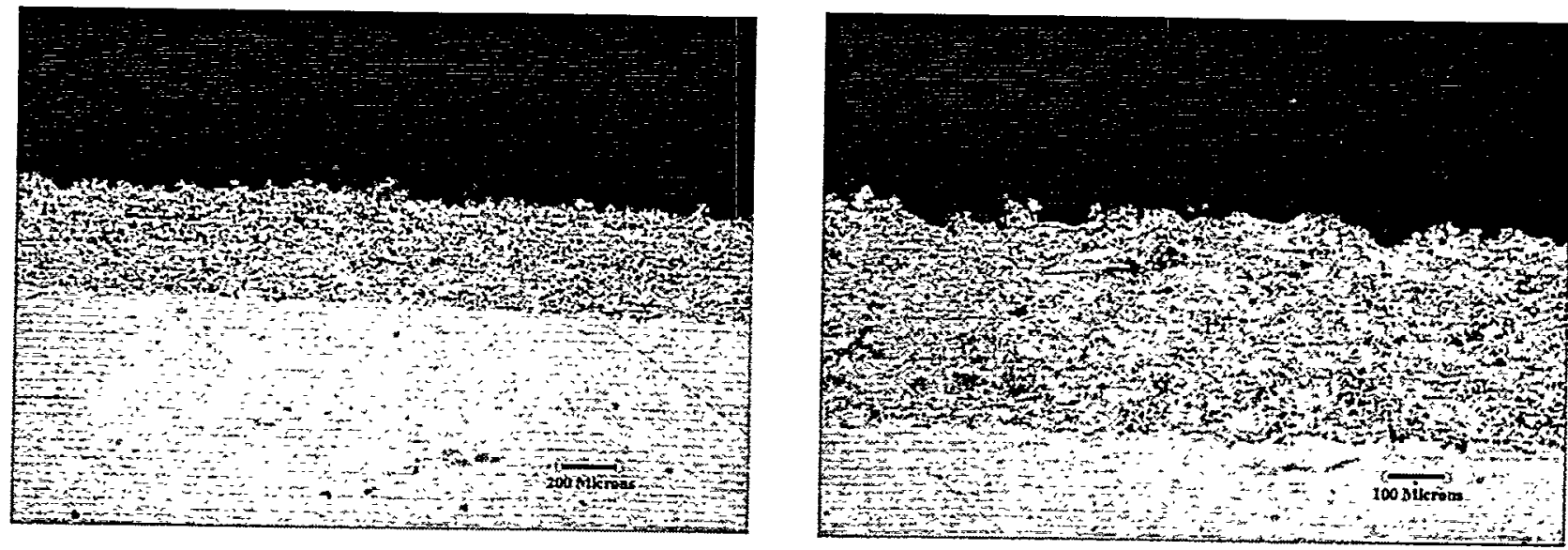

Figure 3. Cross sections of plasma sprayed Metco 450 at 50X and 100X magnification.
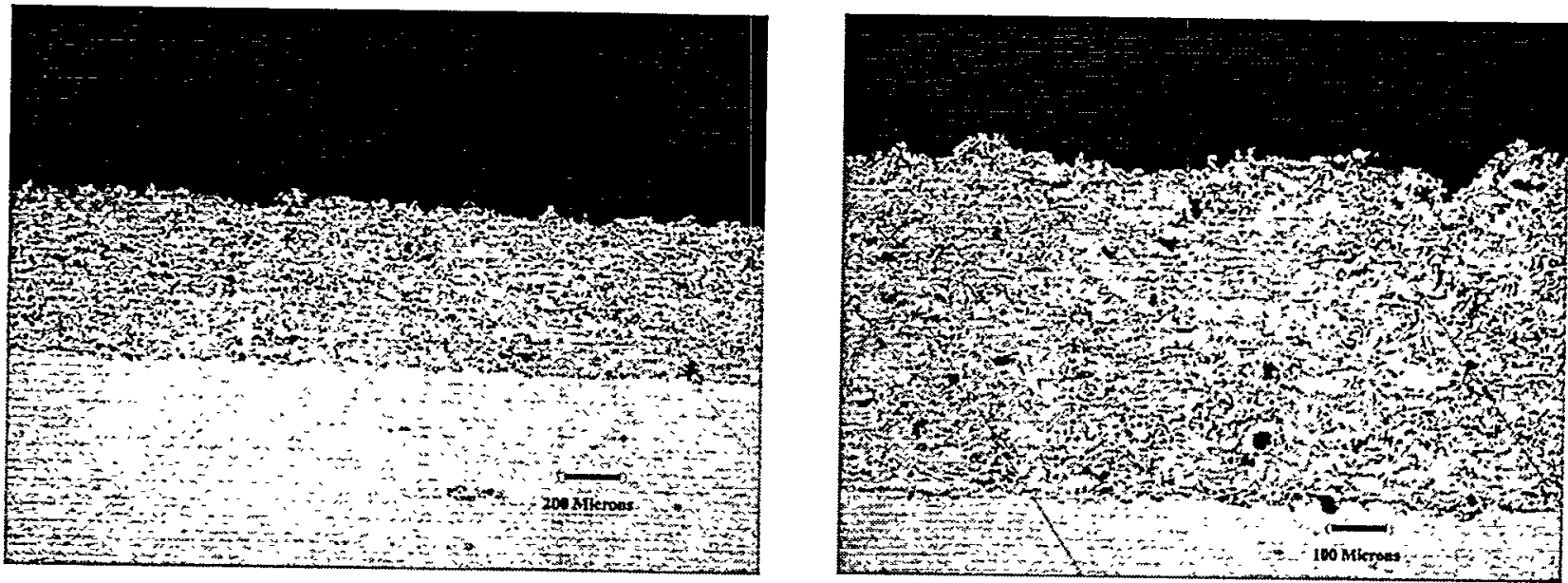

Figure 4. Cross sections of plasma sprayed Metco 480 at 50X and 100X magnification. 

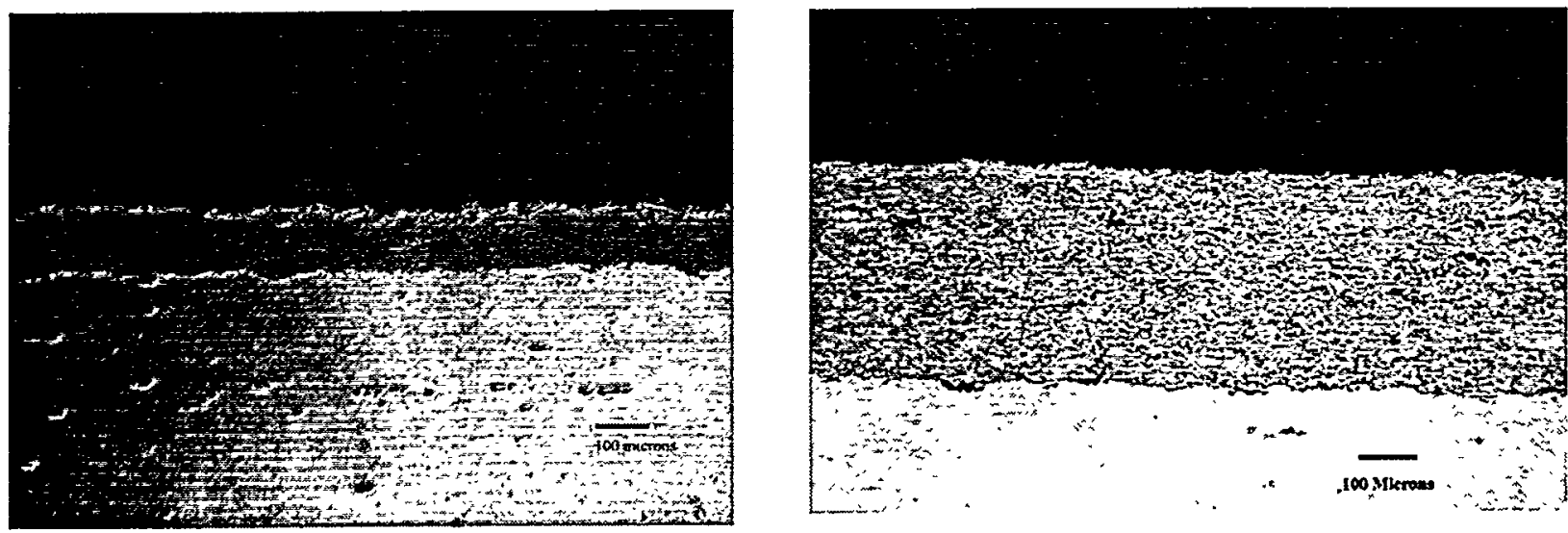

Figure 5. Cross sections of plasma sprayed X-form 205 at 50X and 100X magnification.
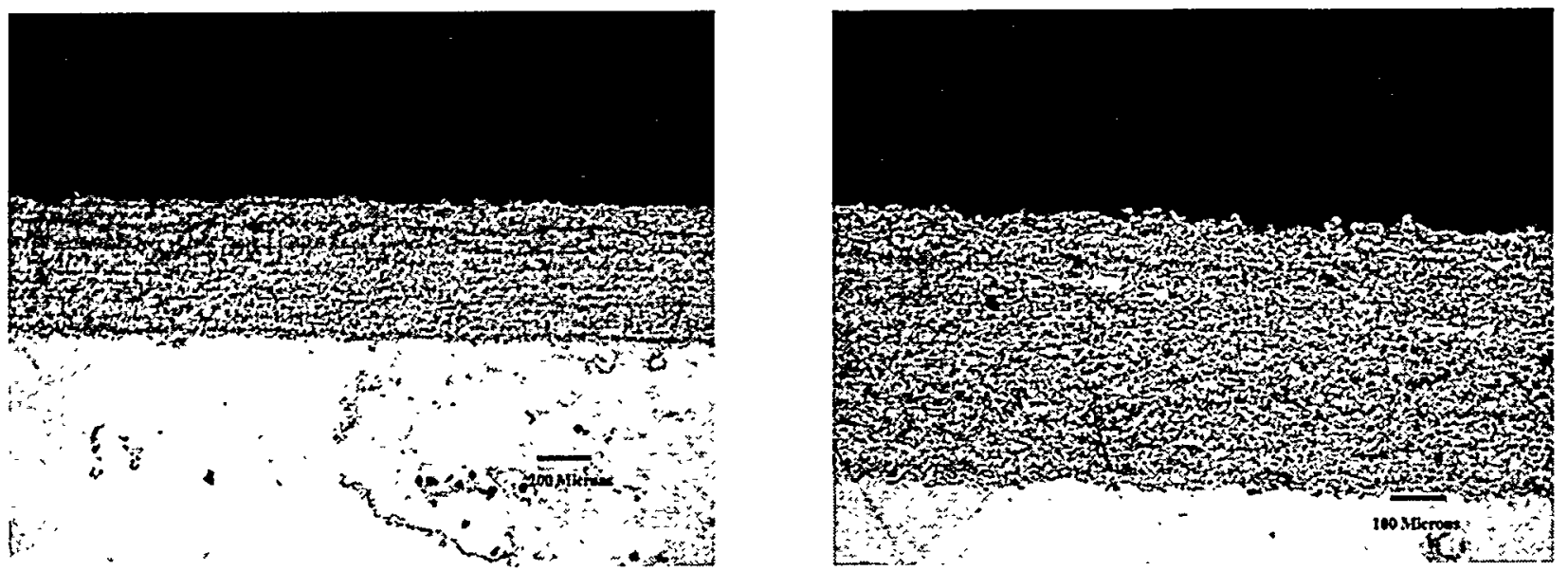

Figure 6. Cross sections of plasma sprayed Ametek IC-50 at 50X and 100X magnification. 

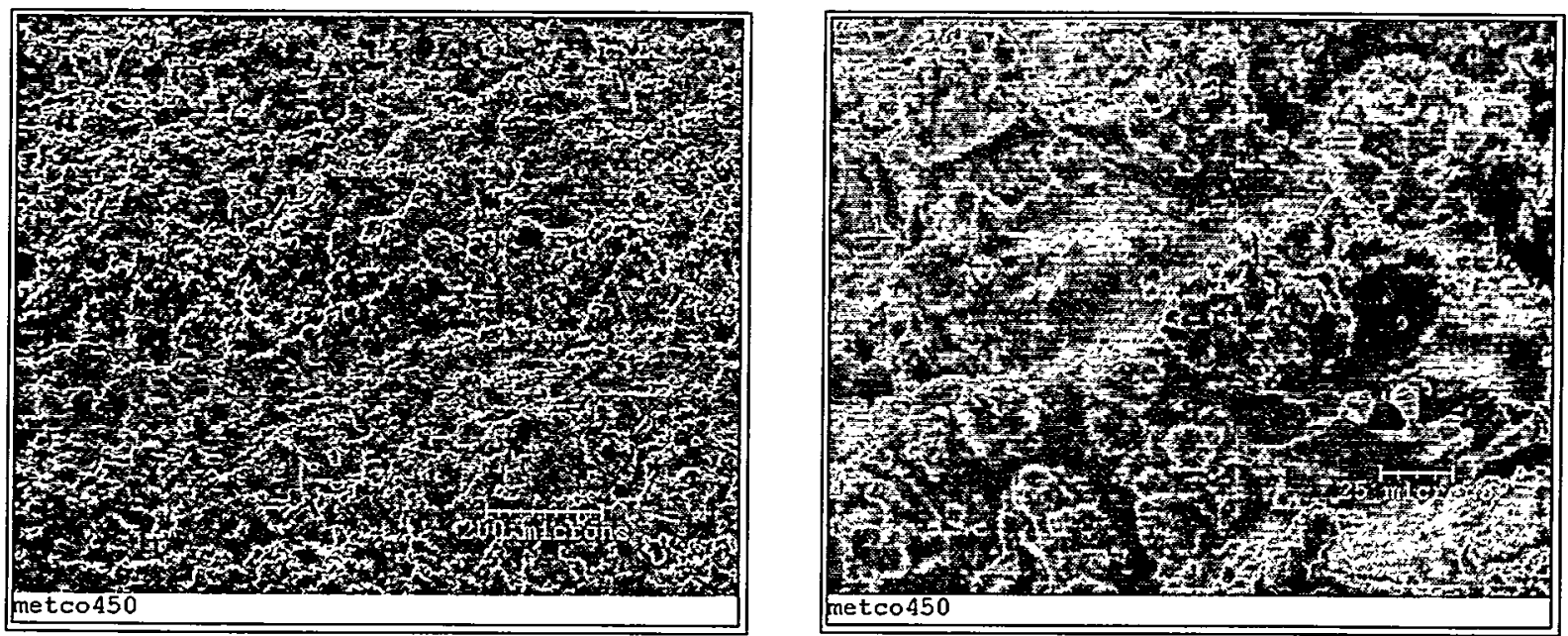

Figure 7. SEM micrographs of Metco 450 surface at $100 \mathrm{X}$ and $500 \mathrm{X}$ magnification.
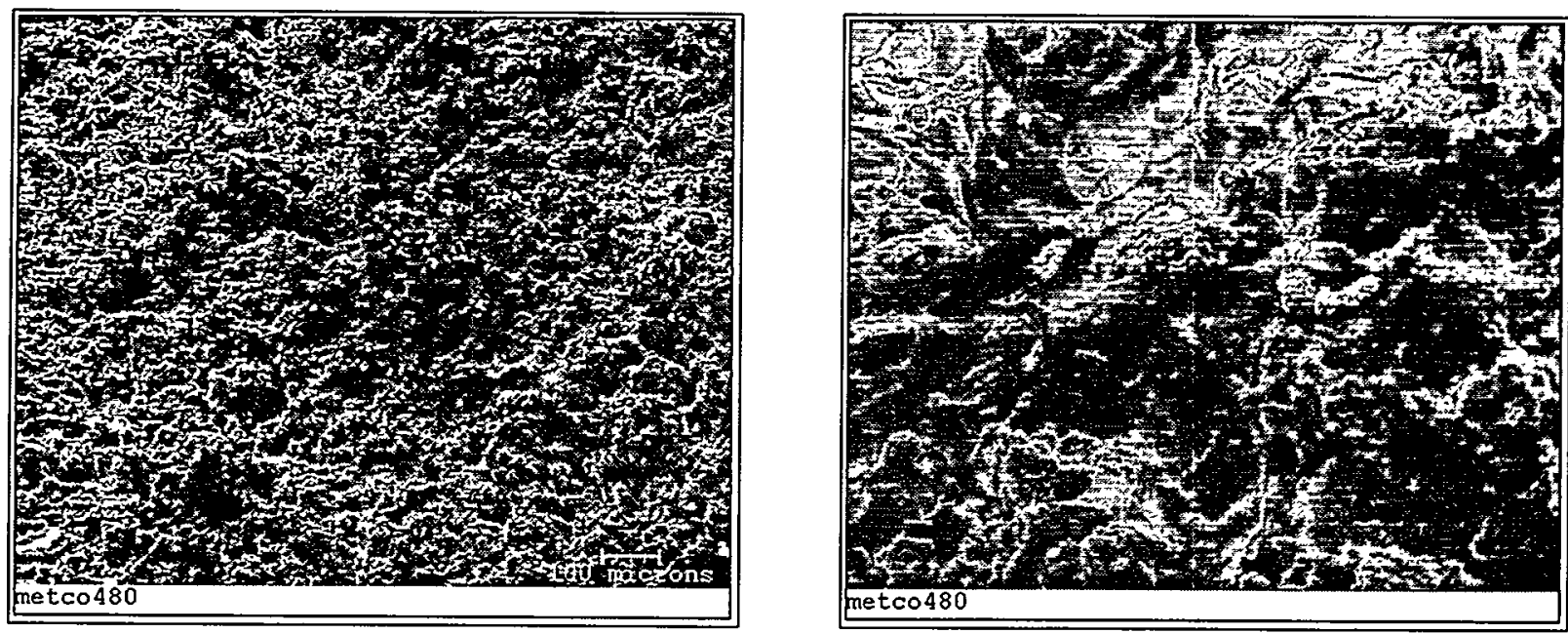

Figure 8. SEM micrographs of Metco 480 surface at 100X and 500X magnification. 

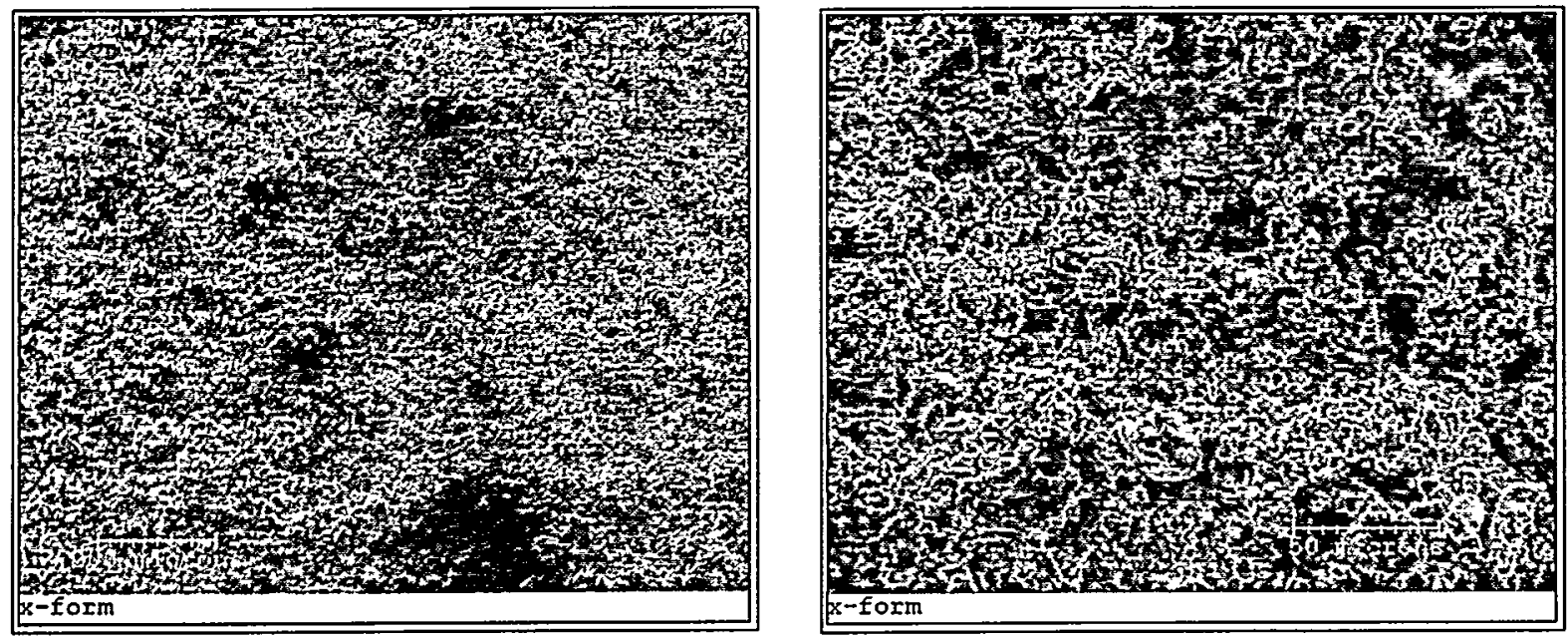

Figure 9. SEM micrographs of $\mathrm{X}$-form 205 surface at $100 \mathrm{X}$ and 500X magnification.
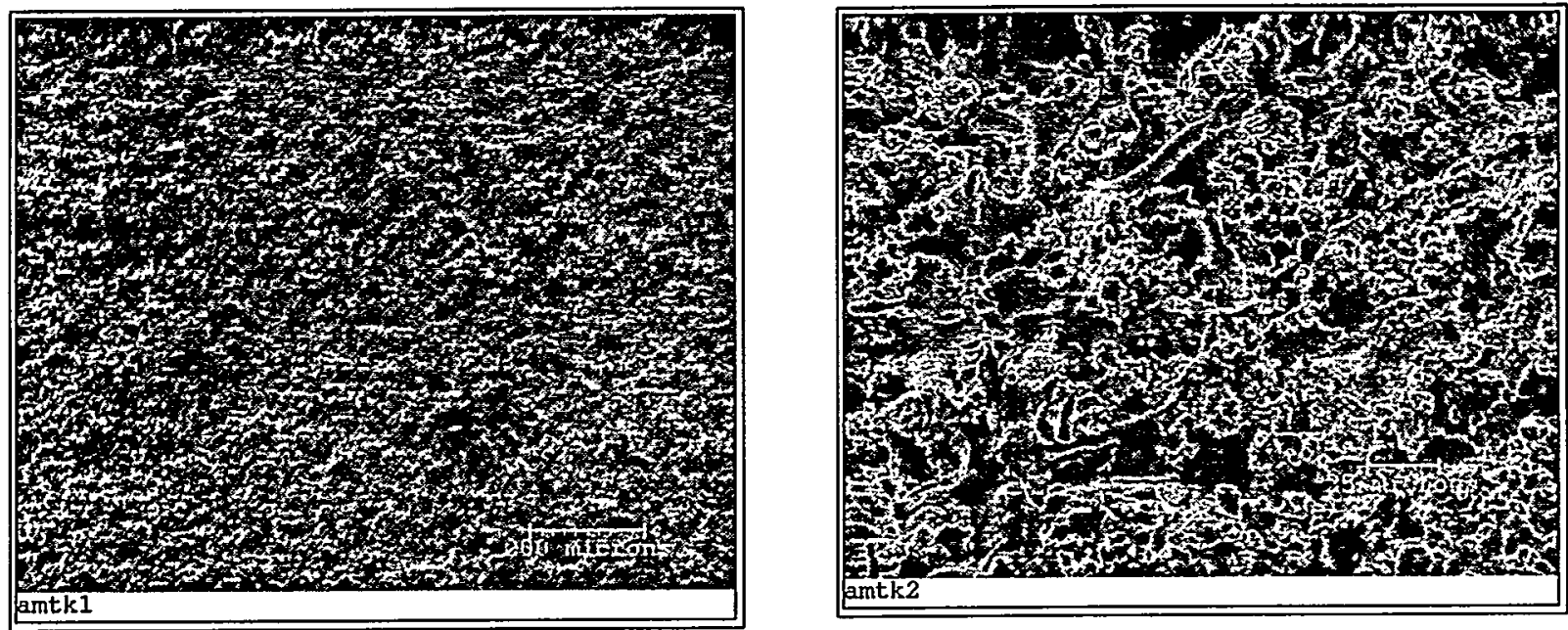

Figure 10. SEM micrographs of Ametek IC-50 surface at $100 \mathrm{X}$ and 500X magnification. 

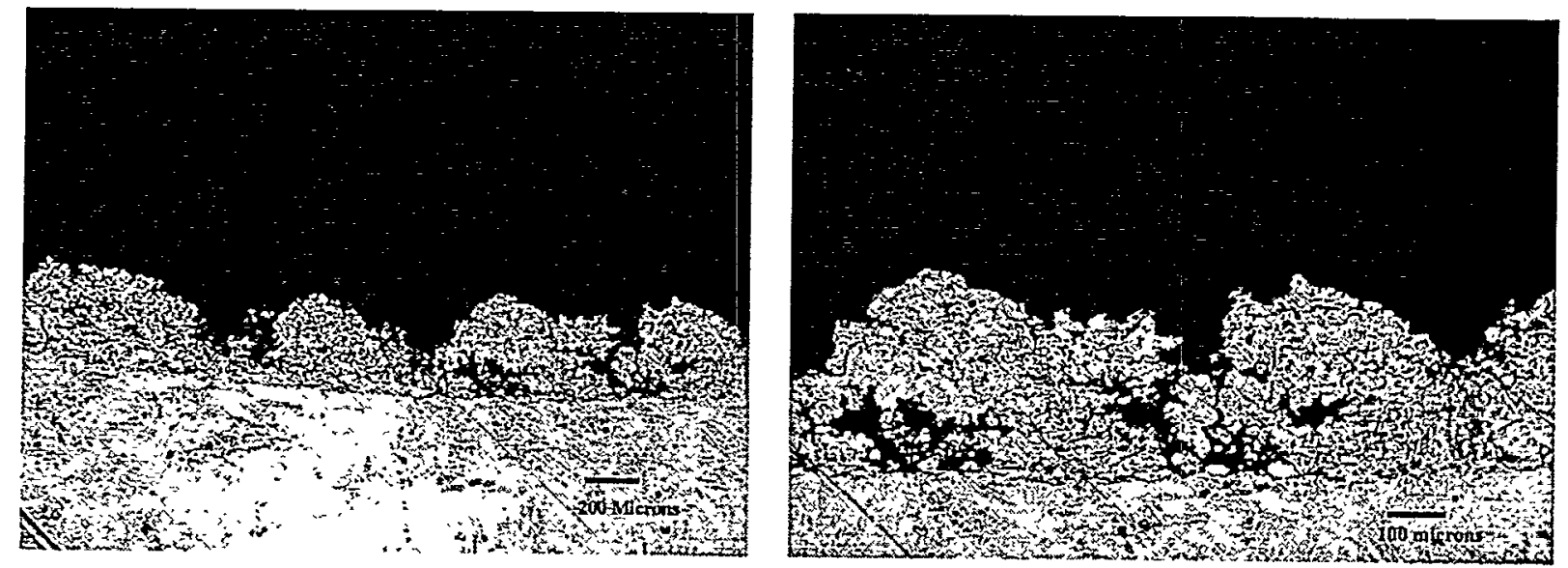

Figure 11. Cross sections of plasma sprayed Metco 480 on tube ends at 25X and 50X magnification.
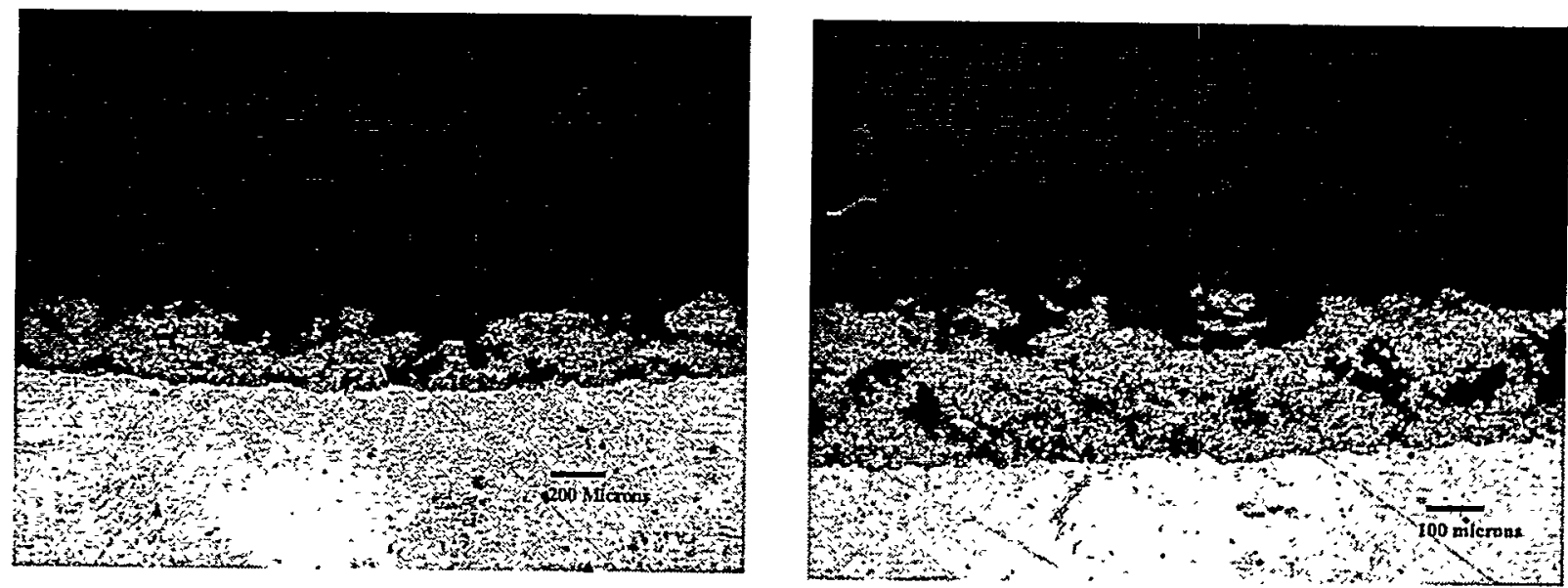

Figure 12. Cross sections of plasma sprayed X-form 205 on tube ends at $25 \mathrm{X}$ and $50 \mathrm{X}$ magnification. 

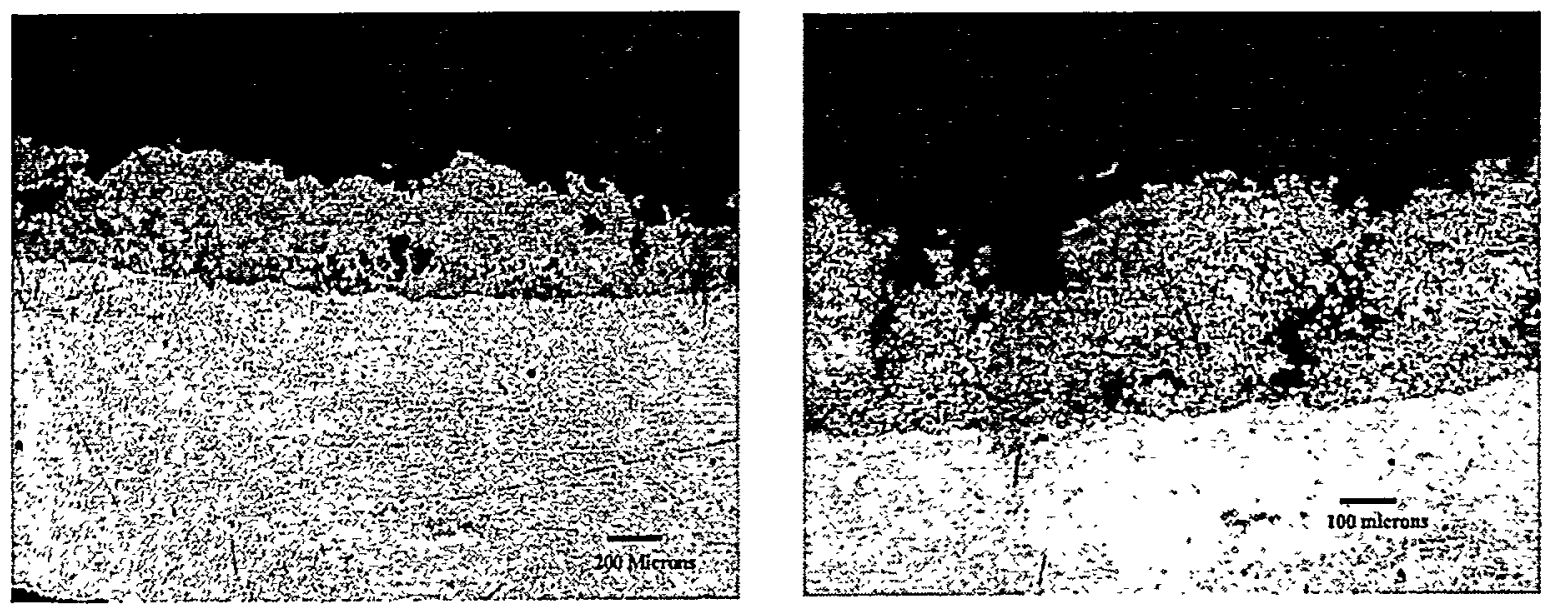

Figure 13. Cross sections of plasma sprayed Ametek IC-50 on tube ends at $25 \mathrm{X}$ and $50 \mathrm{X}$ magnification.
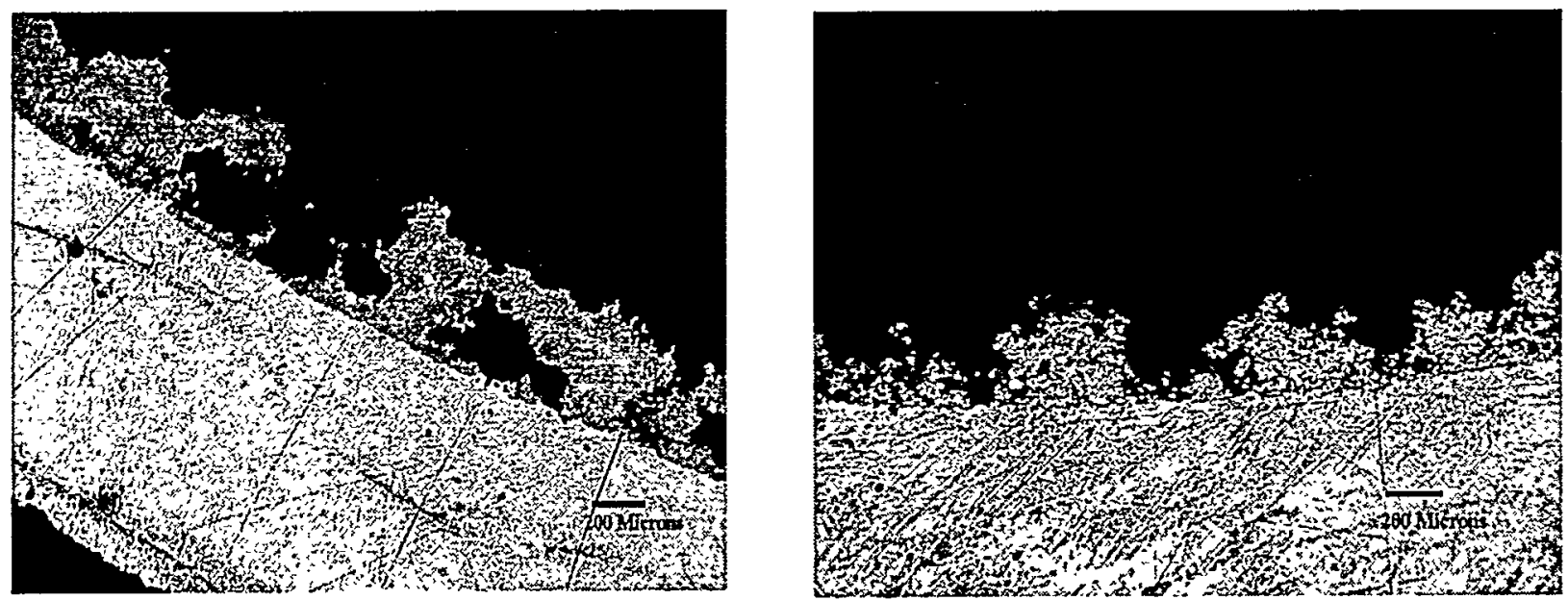

Figure 14. Further cross sections of plasma sprayed Ametek IC-50 and Metco 480 on tube ends at $25 \mathrm{X}$ magnification showing areas of poor quality coating. 
The flame sprayed Metco 450 coating in Figure 2 has higher porosity than the same material when plasma sprayed as expected. The X-form 205 and Ametek IC-50 coatings have lower porosity and finer microstructure than the other two. Striations in the Ametek IC-50 coating are associated with multiple passes of the plasma spray gun to build up the coating thickness. The SEM micrographs at $100 \mathrm{X}$ show the different surface textures of the four coatings. At higher magnification there is clear distinction in the degree of particle melting. The Metco 480 coating had the greatest degree of melting. Some unmelted particles were retained on the surface of Metco 450 . This is related to the different feedstock processing (gas atomized versus clad). Both the Ametek IC-50 and Xform 205 coatings exhibit significant proportions of unmelted particles.

The microstructures of the coated tubes (Figures 11 to 14 ) were significantly more porous and less uniform than those obtained on the flat coupons. In addition, the coating thickness decreased with increasing distance from the end of the tube. Porosity linking the electrolyte to substrate and bare spots were observed. These features suggest poorer protective capabilities as compared with denser, uniform coatings. Approximately $2 "$ of the tube was coated with Ni-Al.

The results of quantitative EDX analysis of the four coatings are presented in Table 1.

Table 1. EDX Analysis of Plasma Sprayed Coatings

\begin{tabular}{|c|c|c|}
\hline Coating & Atomic \%Al & Atomic \%Ni \\
\hline X-form 205 & 30.32 & 69.28 \\
\hline Metco 450 & 11.34 & 88.64 \\
\hline Metco 480 & 15.68 & 84.32 \\
\hline Ametek IC-50 & 19.58 & 80.42 \\
\hline
\end{tabular}

\subsection{X-Ray Diffraction}

The XRD patterns of the four different coatings are depicted in Figures 15 to 19 . The patterns are overlaid with the known peaks for $\mathrm{Ni}$ and $\mathrm{Al}$. The plasma sprayed Metco 450 shows Ni peaks whereas the flame sprayed material also shows small Al peaks. The spectrum for Metco 480 is virtually the same as that for plasma sprayed Metco 450. The X-form 205 coating appeared to consist primarily of NiAl. The Ametek IC- 50 coating displays a similar spectrum to those obtained for Metco 450 and 480. 
Metco Flame sprayed

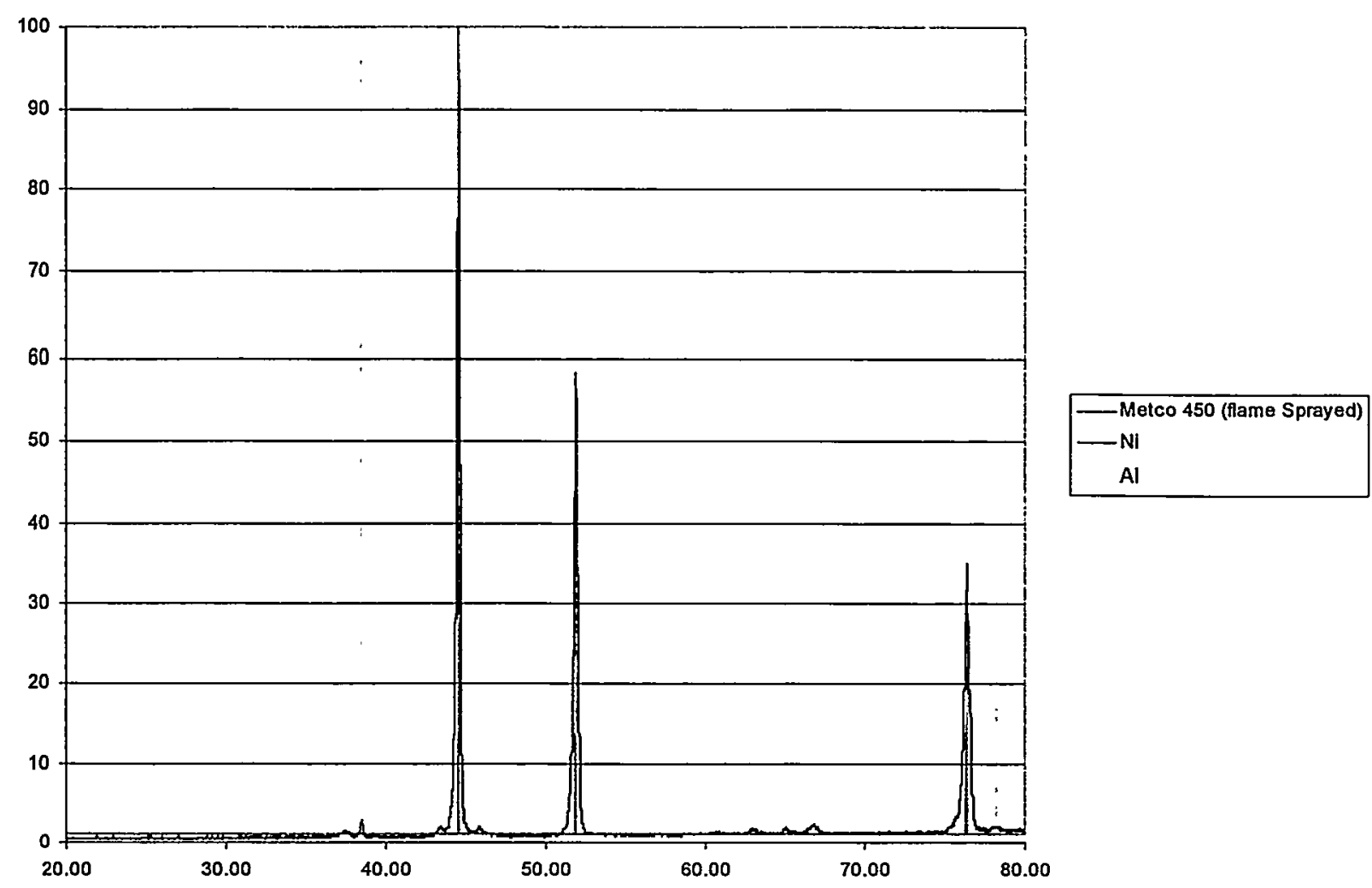

Figure 15. XRD pattern of flame sprayed Metco 450. 
Metco 450 Plasma sprayed Ni-Al with Ni Pattern overlaid

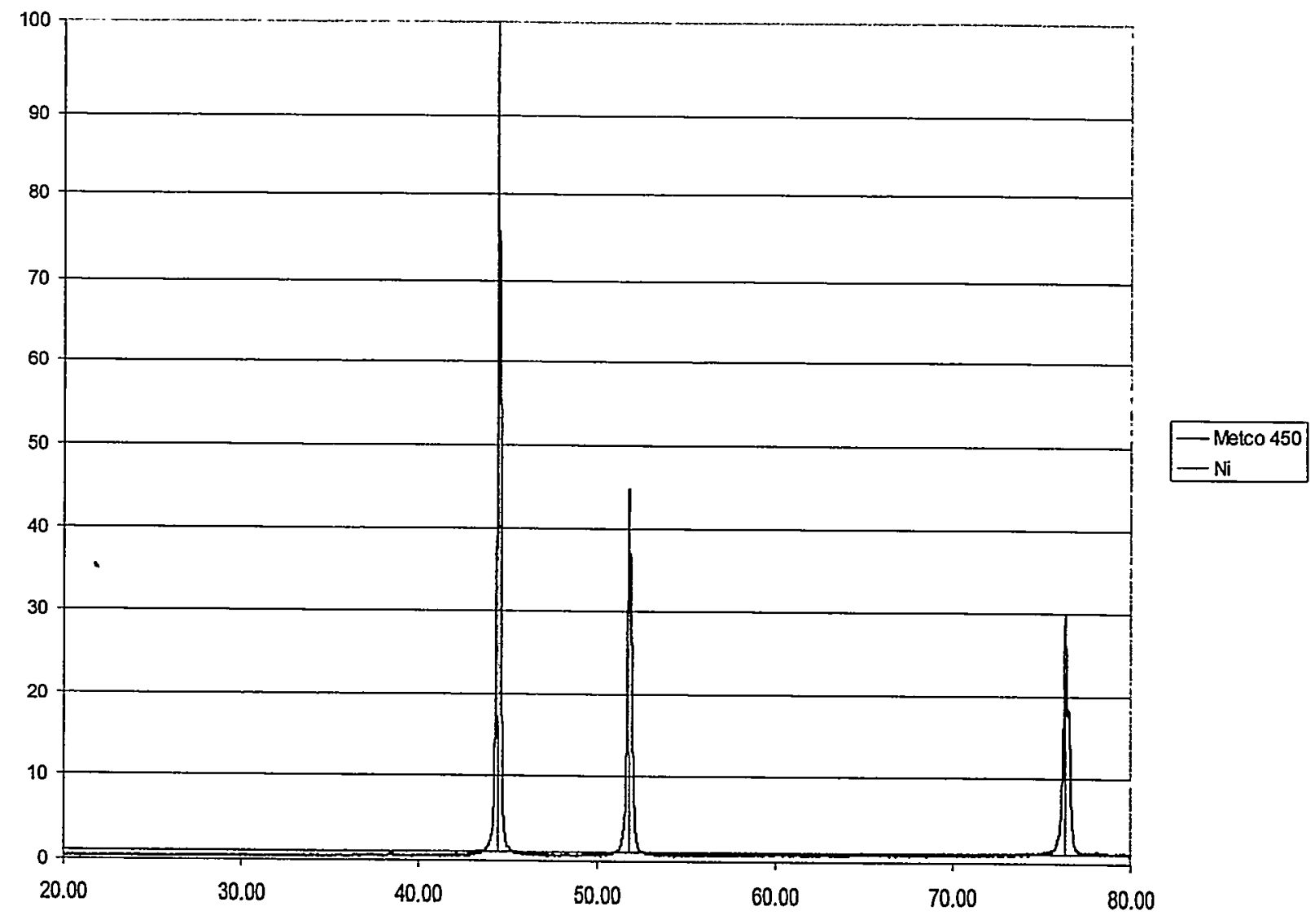

Figure 16. XRD pattern of plasma sprayed Metco 450. 
Metco 480

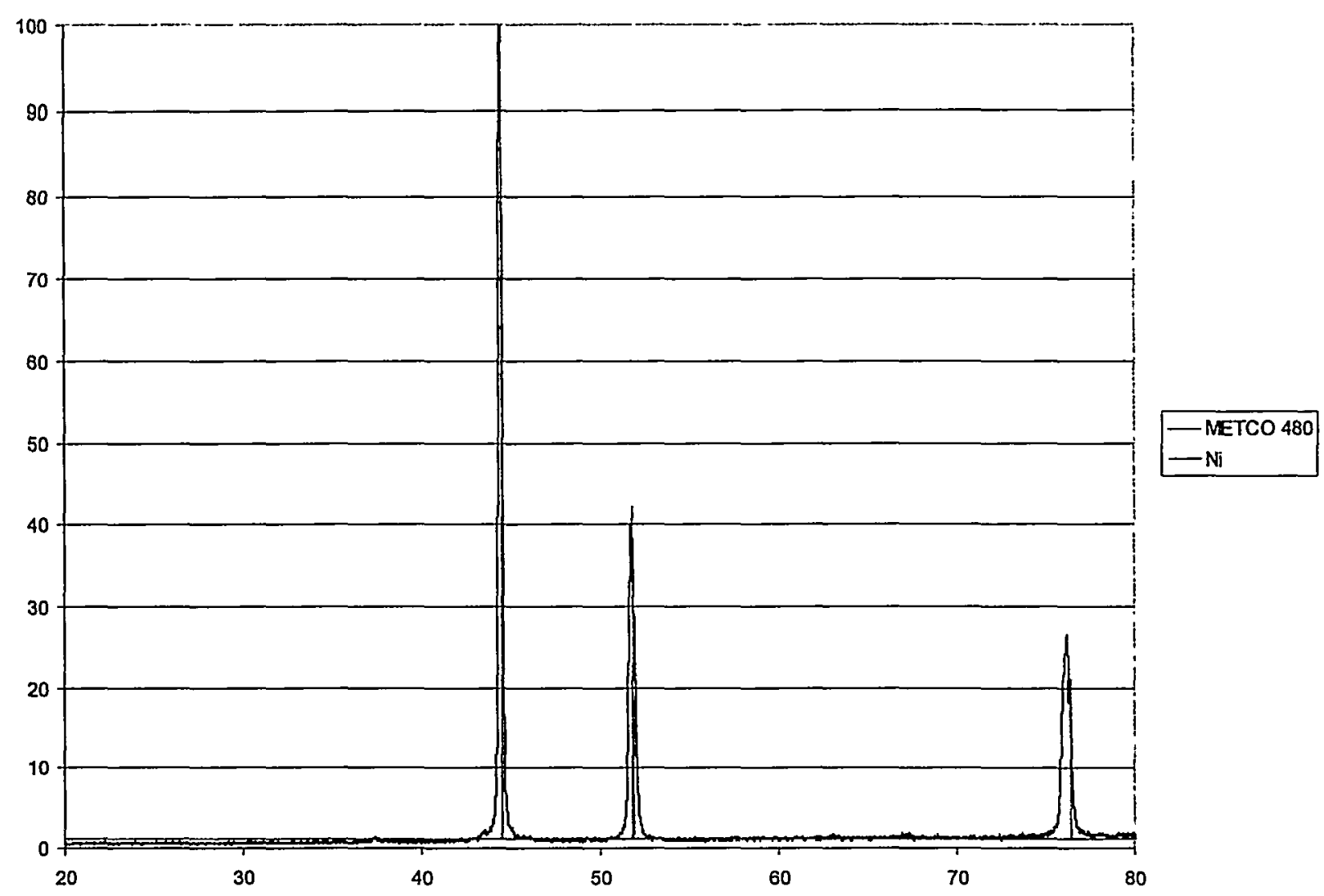

Figure 17. XRD pattern of plasma sprayed Metco 480. 
X-form plasma

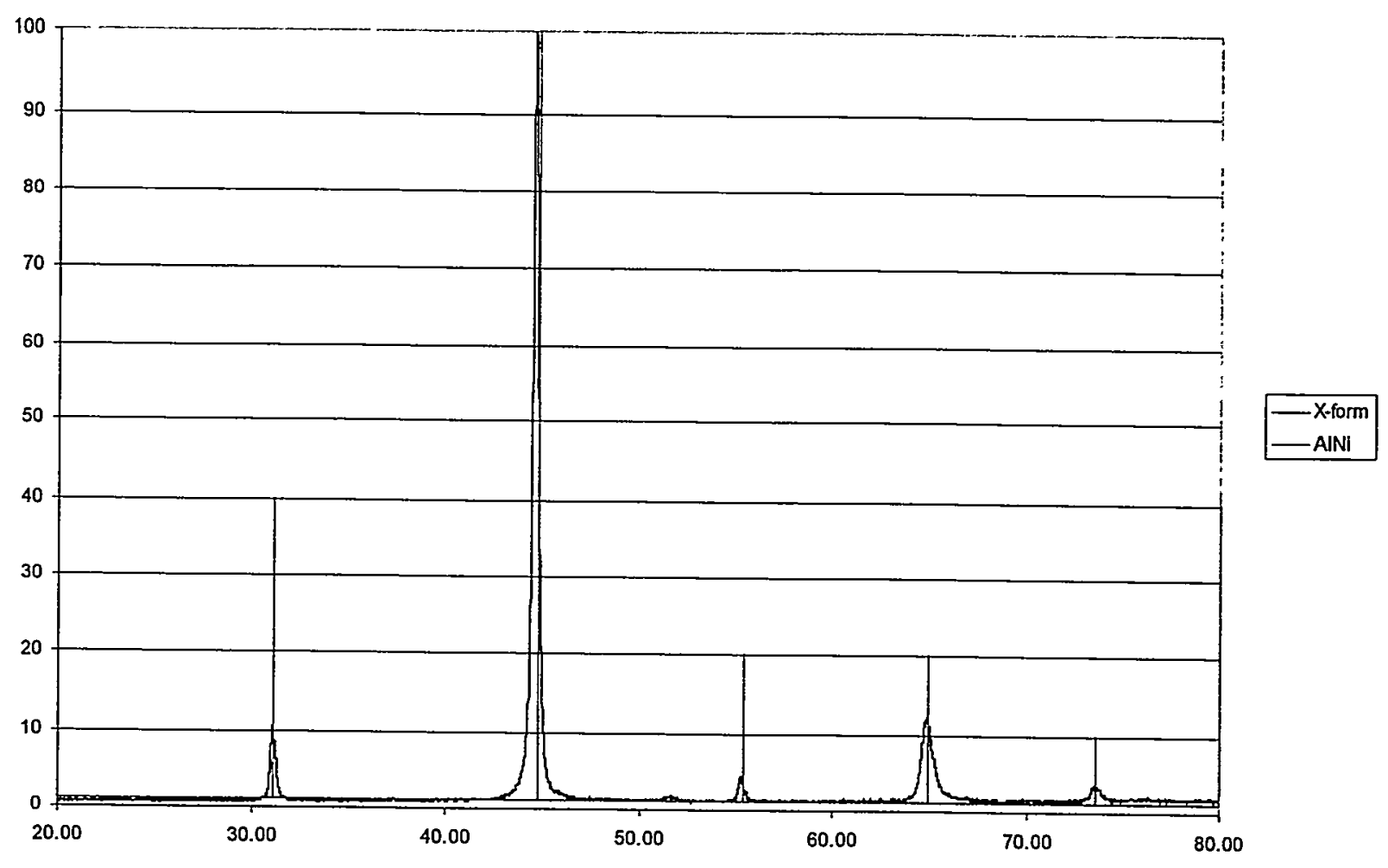

Figure 18. XRD pattern of plasma sprayed X-form 205. 


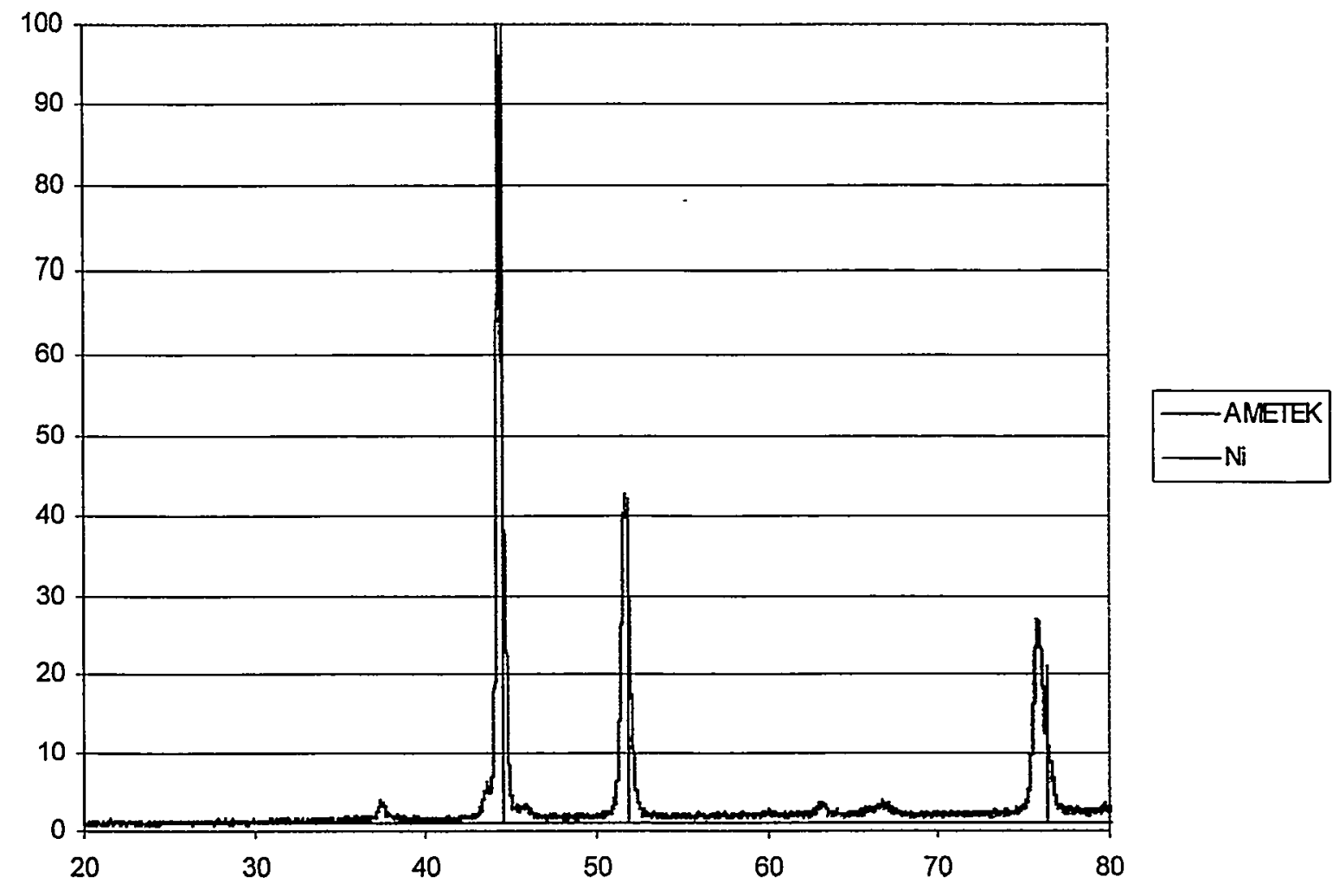

Figure 19. XRD pattern of plasma sprayed Ametek IC-50. 


\subsection{Open Circuit Potentials}

Figure 20 is a plot of open circuit potential versus time for different $\mathrm{Ni}$-Al coatings on flat coupons and bare steel. The open circuit potential, $\mathrm{E}_{\text {corr }}$, of bare steel rapidly became more active on exposure to brine. This was followed by a transition to more noble potentials after eight days. The changes in $\mathrm{E}_{\mathrm{cor}}$ are probably due to formation iron chlorides, iron oxides and iron hydroxides on the steel surface. Film formation results in more positive potentials, whereas a decrease in potential is associated with film breakdown. As expected, $E_{\text {cor }}$ for steel was typically more negative than the values for other materials measured at the same time. $E_{\text {cor }}$ for flame sprayed Metco 450 oscillated for a few days and then showed a more noble trend. Other than the initial reading, $\mathrm{E}_{\text {corr }}$ for the equivalent plasma sprayed coating was consistently more noble and tended to become more positive with time. This suggests, in qualitative terms, better protection afforded by the plasma sprayed material. $\mathrm{E}_{\text {corr }}$ only gives a thermodynamic comparison of the materials rather than corrosion rate rankings. The X-form 205 coating was initially the most noble of all materials tested. $\mathrm{E}_{\text {corr }}$ became more negative over the first few days and then paralleled the values measured on plasma sprayed Metco 450.

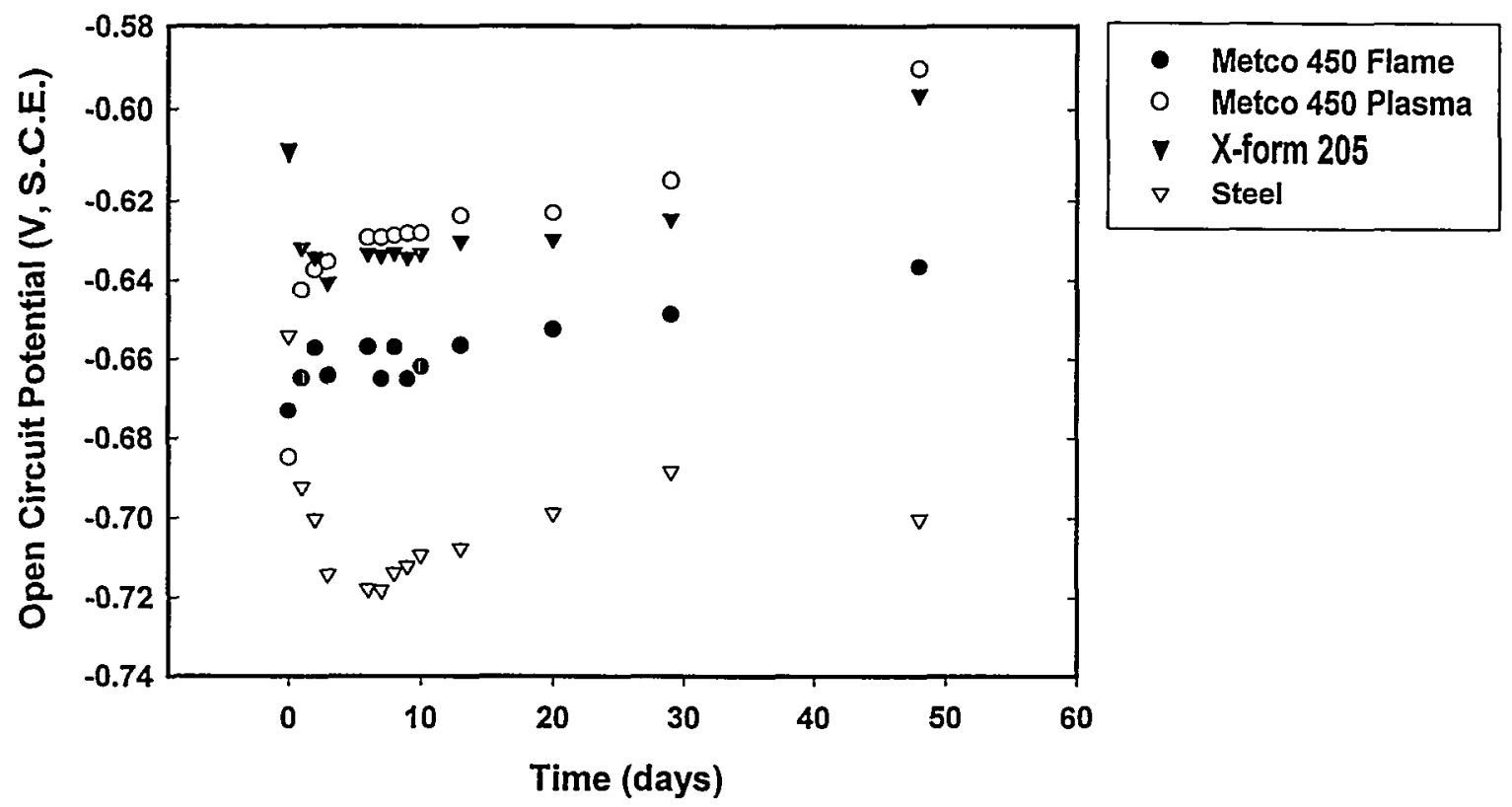

Figure 20. Open circuit potentials versus time for different coatings.

The open circuit potential on sprayed $\mathrm{Ni}$-Al tube ends exposed to brine at room temperature was measured for one week and compared with that for PPS and ST/TMPTMA liners. Potentials 
were also measured on six inch long tubes with one half sprayed with Metco 480 and the other half coated with either PPS or ST/TMPTMA. The potentials on the sprayed tubes were typically within the range of -0.63 to $-0.67 \mathrm{~V}$ (S.C.E.). It was observed that the measured potential depended on the position of the reference electrode with respect to the axial length of the tube. Potentials were more positive near the tube end and this was associated with greater coating thickness. The most significant finding was that potentials on the sprayed $\mathrm{Ni}-\mathrm{Al}$ tube ends were consistently more active than those for tubes with composite liners. This suggests that the Ni-Al coatings will corrode preferentially to the liners for the experimental conditions and this raises concern about the suitability for the application. Corrosion behaviour will be different at the higher temperatures and under flowing conditions occurring in heat exchanger tubes. Also, deposition of scale on $\mathrm{Ni}-\mathrm{Al}$ coatings may influence corrosion rate.

\subsection{Potentiodynamic Polarization Curves}

The polarization curves are depicted in Figures 21 to 25 . The curves labelled 1 and 2 in the figures are for replicate specimens. The other curves are repeat tests on the same specimen. The results for all the coatings are compared in Figure 25. The curves show the changes in open circuit potentials and corresponding current densities for the different coatings. None of the Ni-Al coatings showed passivity over the potential range measured. The coated coupons did not display well defined charge transfer behaviour. Also, extrapolations of the linear portions of the anodic and cathodic curves did not intersect with $E_{\text {corr }}$. This may be due to surface changes occurring during polarization.

The coatings show variable behaviour in terms of $E_{\text {corr, }} i_{\text {corr }}$ and the slopes of the anodic and cathodic branches. This is attributed to the heterogeneous nature of the thermal sprayed coatings. For example, a single pore that connects the substrate with the surface will result in significantly different corrosion characteristics. Owing to the lack of consistency, it is difficult to determine which of the coatings provides the best corrosion protection based on these results. Of the four coatings, Metco 480 was the most consistent. 


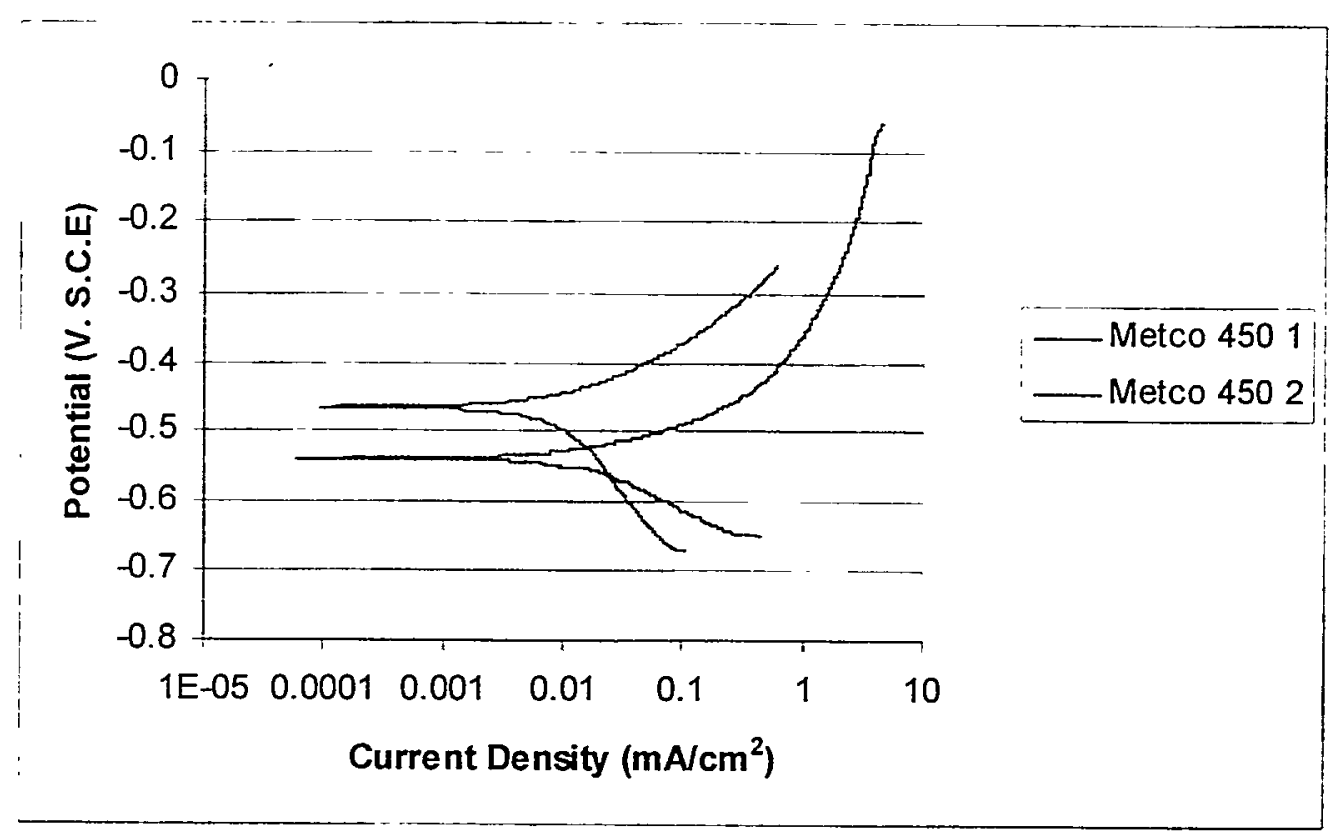

Figure 21. Polarization curve for Metco 450 coating in hypersaline brine. 


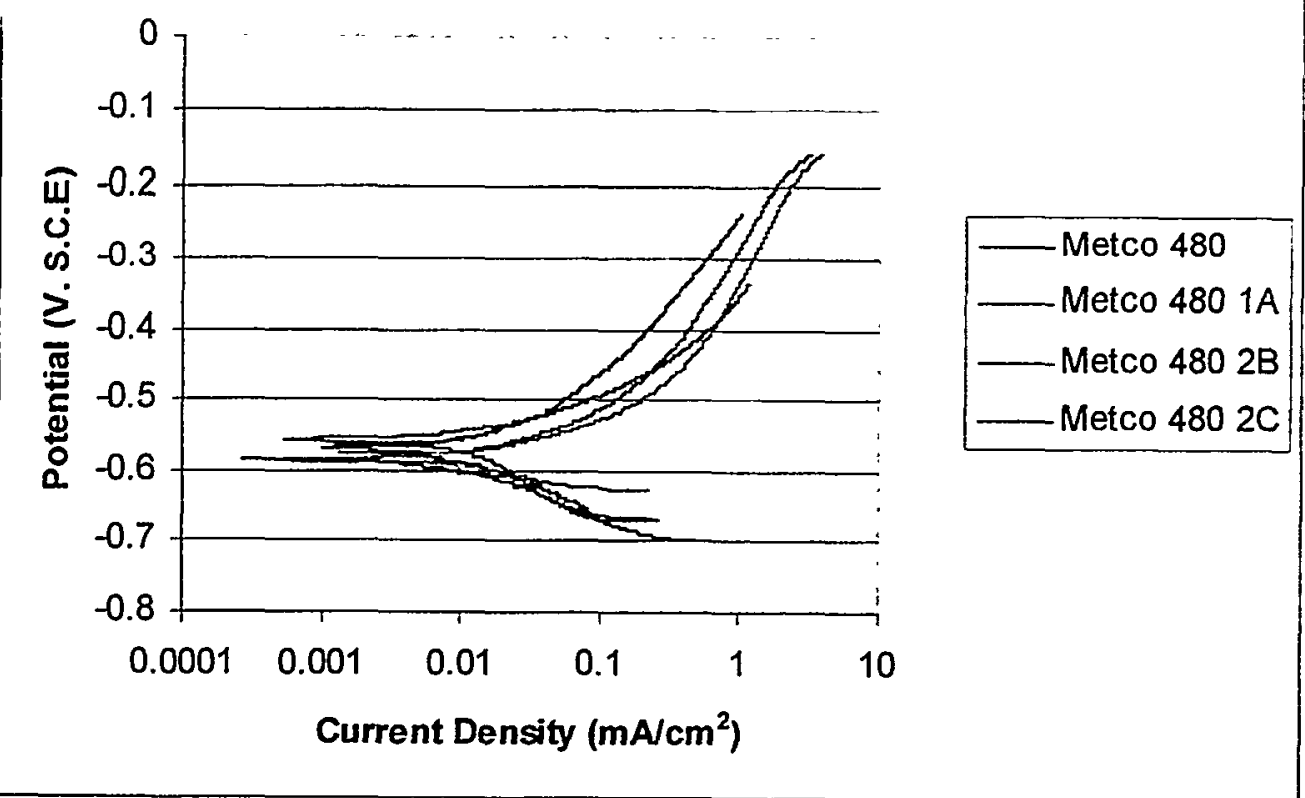

Figure 22. Polarization curve for Metco 480 coating in hypersaline brine. 


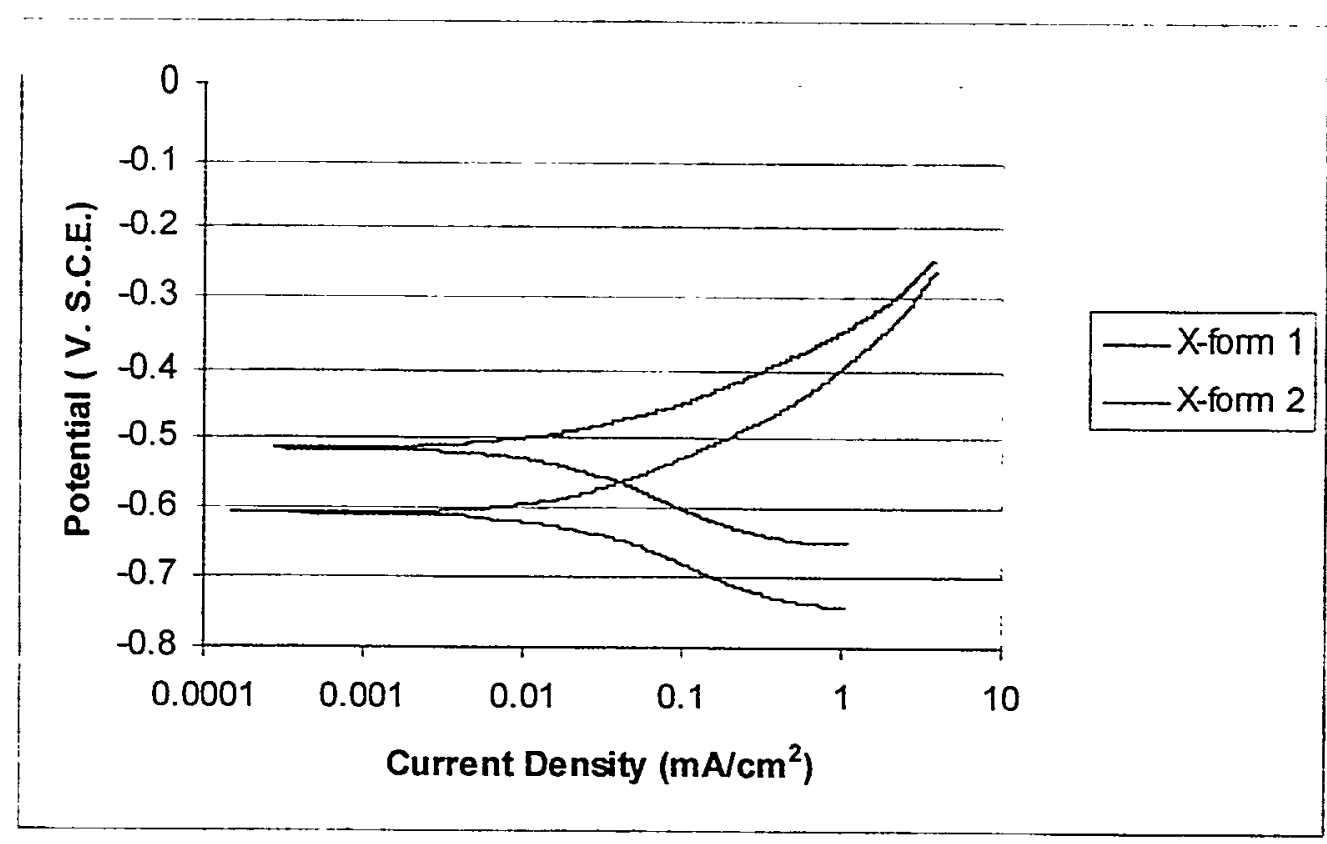

Figure 23. Polarization curve for $\mathrm{X}$-form 205 coating in hypersaline brine. 


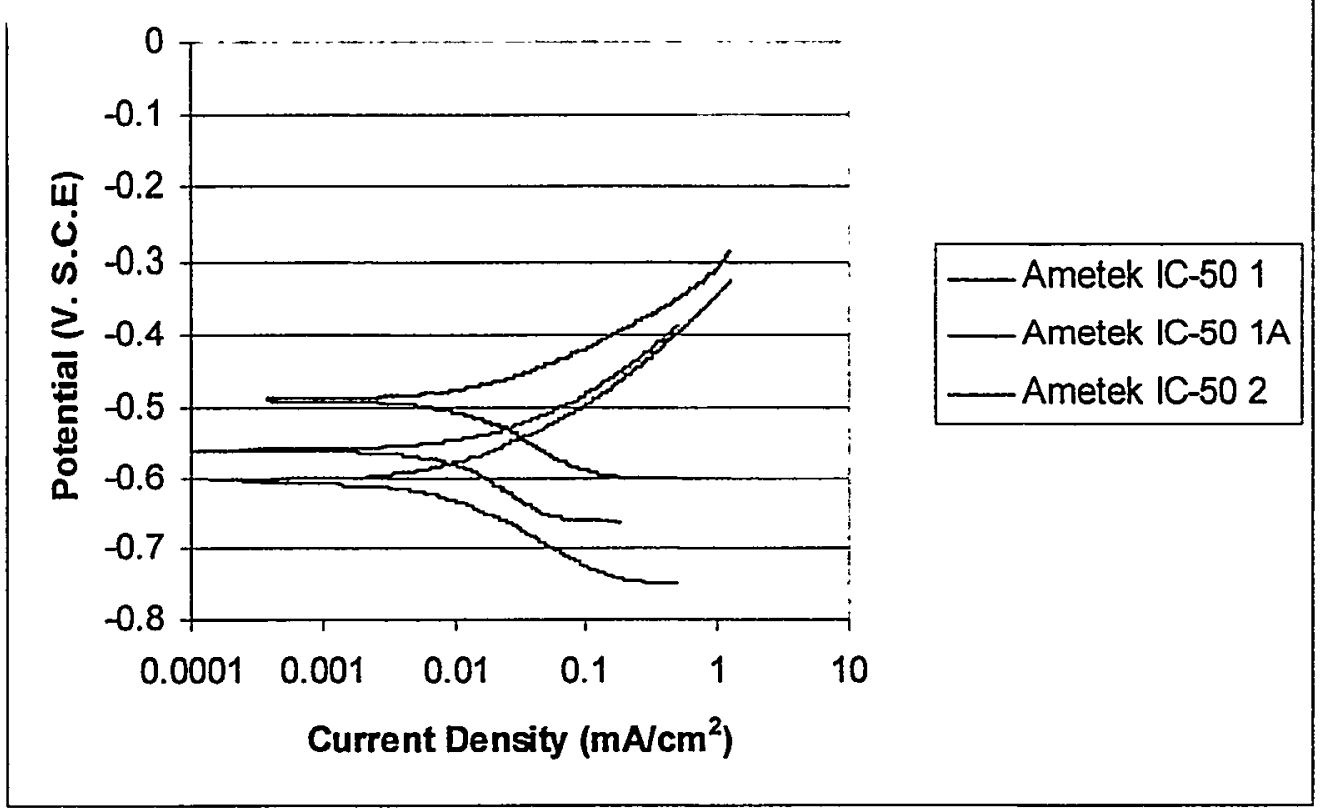

Figure 24. Polarization curve for Ametek IC-50 coating in hypersaline brine. 

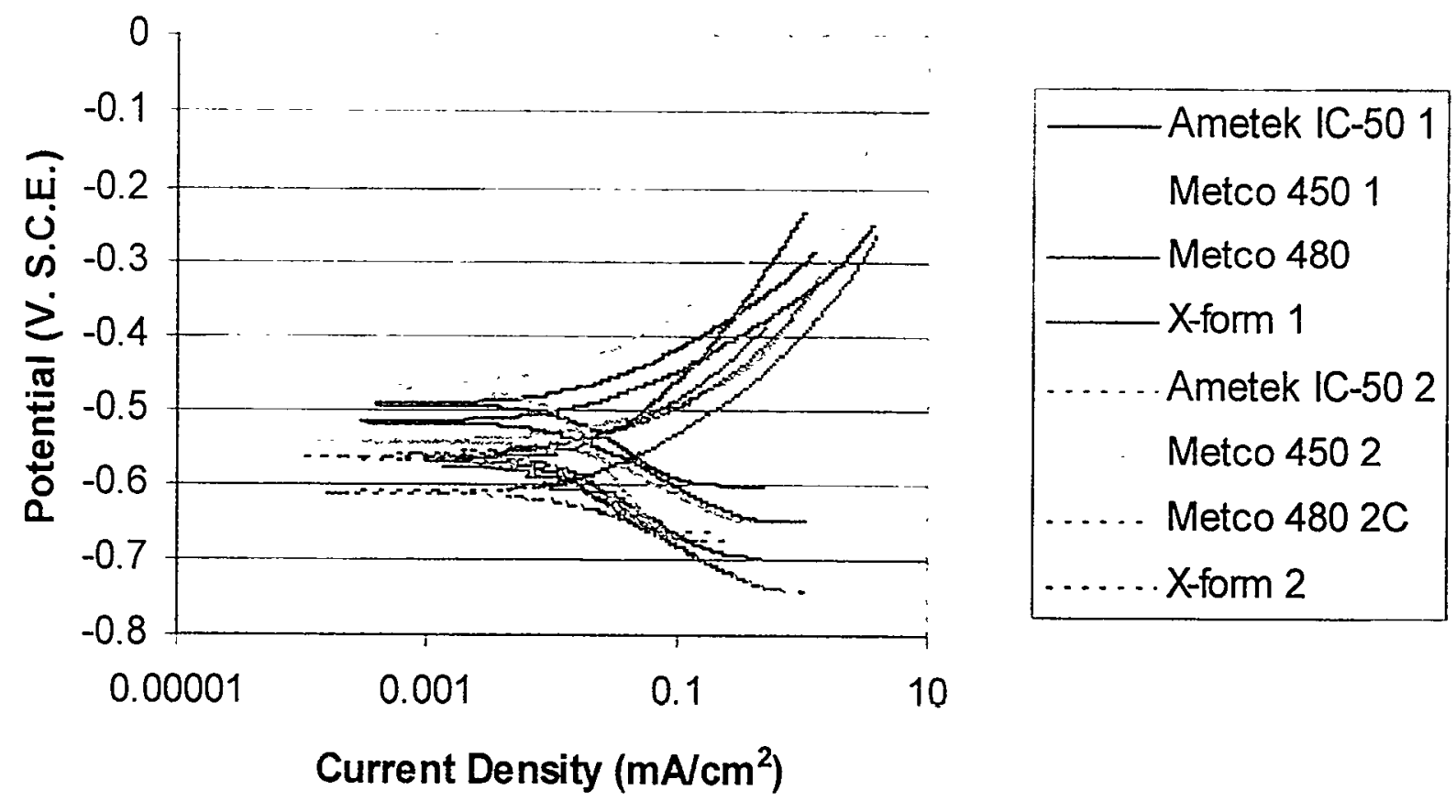

Figure 25. Summary of polarization curves. 


\subsection{Tensile Adhesion Strength}

The results of the tensile adhesion tests are summarized in Table 1 and illustrated in Figure 26. The error bars represent one standard deviation. The results indicate that the Metco $480 \mathrm{Ni}$ 5Al, pre-alloyed) had the lowest bond strength. The values for the IC-50 (Ni-Al-B) and Metco 450 (Ni-5Al, clad) were similar. The X-form 205 coating was the most variable. The mode of failure was not consistent within a coating group. In general terms, failure was predominantly cohesive for the Metco 480 coating.

The results can be compared with those published in the literature. McPherson and Cheang (1989) found higher tensile adhesion strength on pre-alloyed Ni-Al than clad feedstock. Svantesson and Wigren (1992) measured an average tensile adhesion strength of different $\mathrm{Ni}-5 \mathrm{Al}$ coatings on an Inconel 718 substrate. Clad Ni-5Al powders with minimal B produced adhesion strengths ranging from 52.2 to $55.3 \mathrm{MPa}$. Strengths for the coatings prepared from gas and water atomized powders varied with chemistry and ranged from 38.4 to $65.3 \mathrm{MPa}$. The highest adhesion strength was achieved with the material containing $0.2 \% \mathrm{~B}$. This concurs with the high strength measured for the Ametek IC-50 coating which contained B.

Table 2. Tensile adhesion strength of different plasma sprayed Ni-Al coatings.

\begin{tabular}{|c|c|c|c|c|}
\hline \multirow{2}{*}{ Coating } & \multicolumn{4}{|c|}{ Tensile Adhesion Strength (MPa) } \\
\cline { 2 - 5 } & Mean & $\begin{array}{c}\text { Standard } \\
\text { Deviation }\end{array}$ & Minimum & Maximum \\
\hline X-form 205 & 50.0 & 14.3 & 22.0 & 74.0 \\
\hline Metco 450 & 70.9 & 4.9 & 58.4 & 74.8 \\
\hline Metco 480 & 39.2 & 5.7 & 26.9 & 48.8 \\
\hline Ametek IC-50 & 76.9 & 6.5 & 60.8 & 82.9 \\
\hline
\end{tabular}




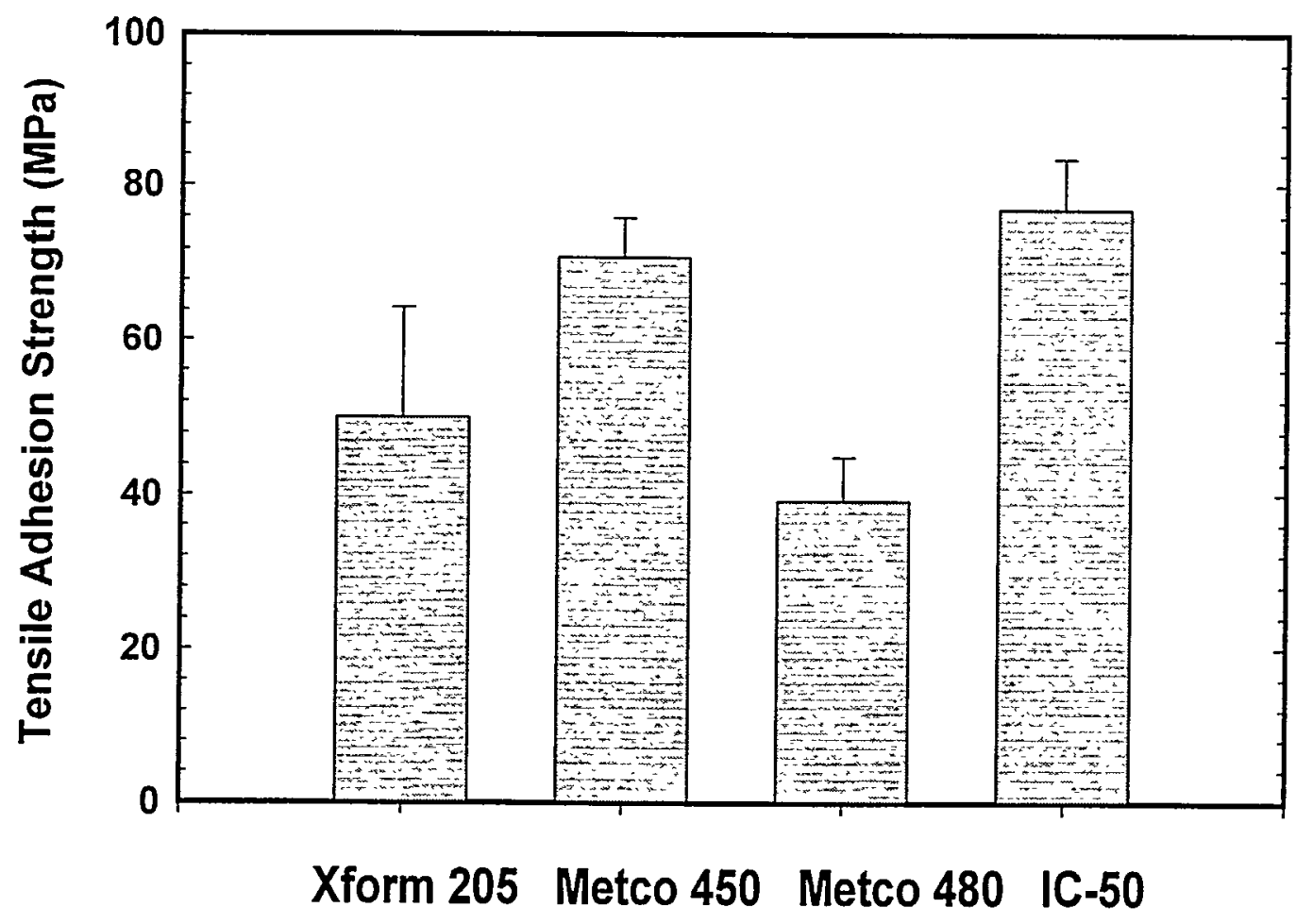

Figure 26. Tensile adhesion strength for different Ni-Al coatings.

\subsection{Microhardness}

The microhardness data is presented in Table 3 and Figure 27. The X-form and IC-50 coatings have significantly higher average microhardness than the other two coatings. This should correlate with greater wear resistance. Khor and Loh (1994) measured the average microhardness to be 139.1 on plasma sprayed pre-alloyed Ni-5Al and 203.4 on clad Ni-20Al. Hot isostatic pressing was found to increase the coating hardness. Average microhardness of ten different Ni-5Al coatings tested by Svantesson and Wigren (1992) ranged from 145 to 203. 
Table 3. Vickers microhardness of different $\mathrm{Ni}-\mathrm{Al}$ coatings.

\begin{tabular}{|c|c|c|c|c|}
\hline \multirow{2}{*}{ Coating } & \multicolumn{4}{|c|}{ Microhardness (VHN) } \\
\cline { 2 - 5 } & Mean & $\begin{array}{c}\text { Standard } \\
\text { Deviation }\end{array}$ & Minimum & Maximum \\
\hline X-form 205 & 293.8 & 26.1 & 247 & 350 \\
\hline Metco 450 & 151.4 & 13.5 & 125 & 177 \\
\hline Metco 480 & 187.5 & 21.3 & 140 & 219 \\
\hline Ametek IC-50 & 276.1 & 29.9 & 213 & 324 \\
\hline
\end{tabular}

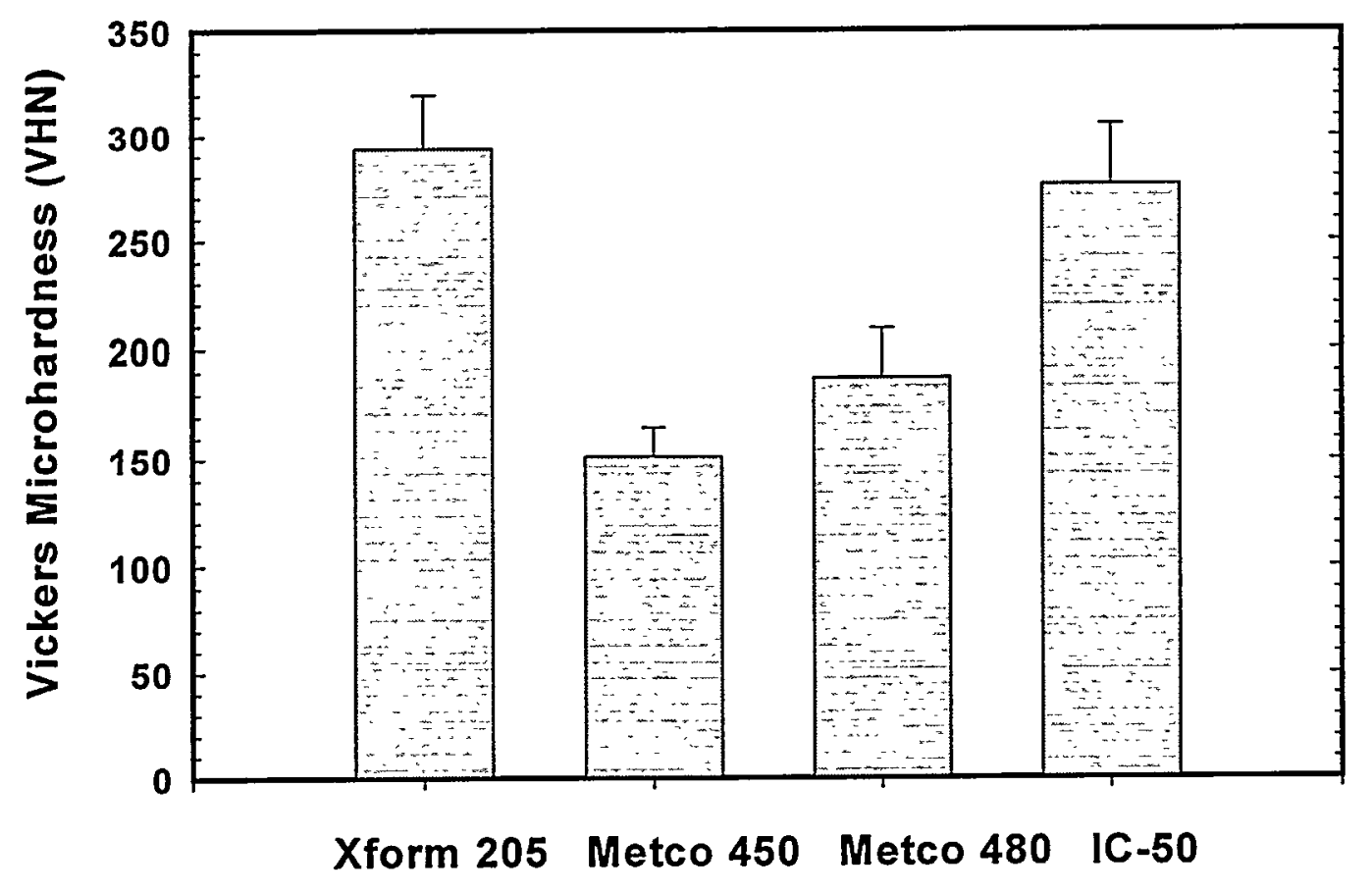

Figure 27. Microhardness of different $\mathrm{Ni}-5 \mathrm{Al}$ coatings. 


\subsection{Field Tests}

One of the $\mathrm{Ni}-5 \mathrm{Al}$ coated coupons exhibited cracks on the edges after testing in the volcanic pool in New Zealand. Some rust stains were apparent on the Ni-5Al coupons. Rust stains were also apparent on the $\mathrm{NiCr}-\mathrm{Cr}_{3} \mathrm{C}_{2}$ and $\mathrm{NiCoCrAlY}$ coated coupons. It is hypothesized that the difficulty in obtaining a uniform coating thickness on the right angle coupon edges resulted in preferential attack at these locations. Aggressive species could have penetrated where the coating was thin or porous on the edges and initiated corrosion. If the coating had been of uniform thickness, the performance may have been better. The ethylene methacrylic acid coating did not show any visible signs of deterioration. This indicates that the material is promising for geothermal applications and it has already been explored for low temperature applications (Allan et al, 1998). Figures 22 to 24 show cross sections of the coupons with alloy coatings where disbondment had occurred. A layer of corrosion products was evident between the coatings and substrates.
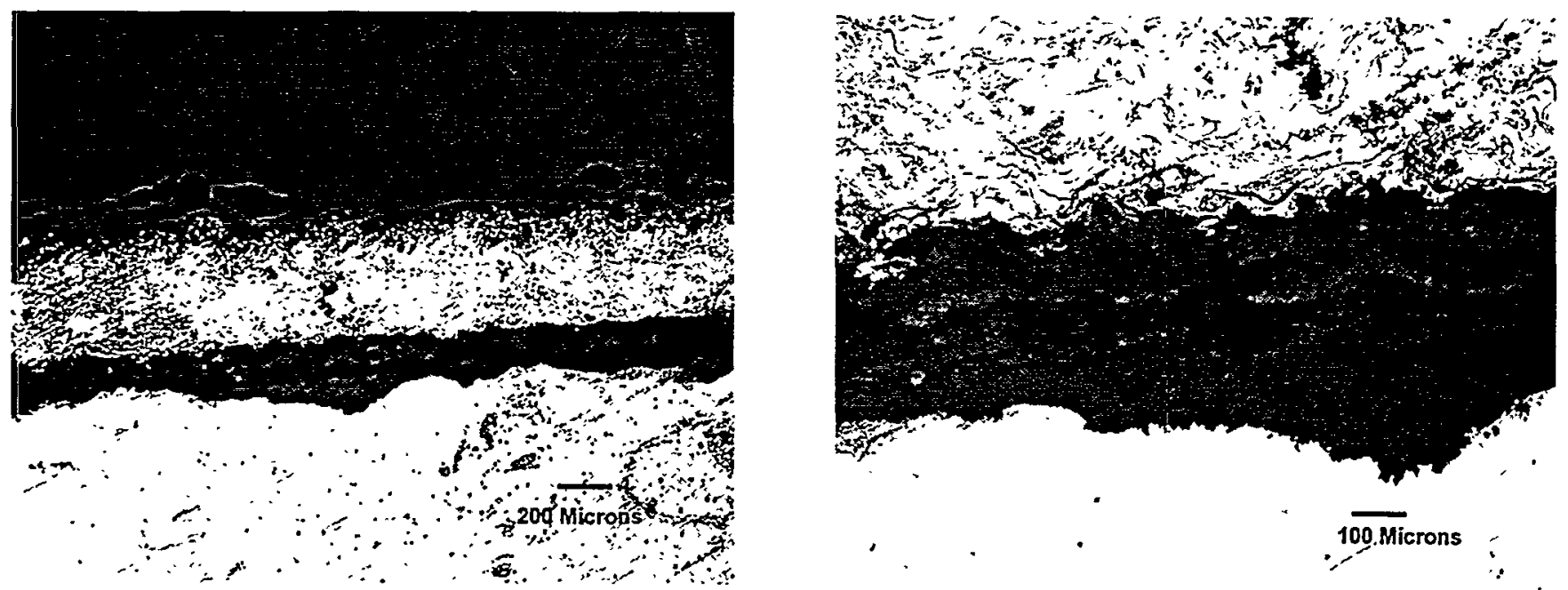

Figure 22. Cross sections of $\mathrm{Ni}-5 \mathrm{Al}$ coating and substrate after exposure (25 and 50X magnification). 

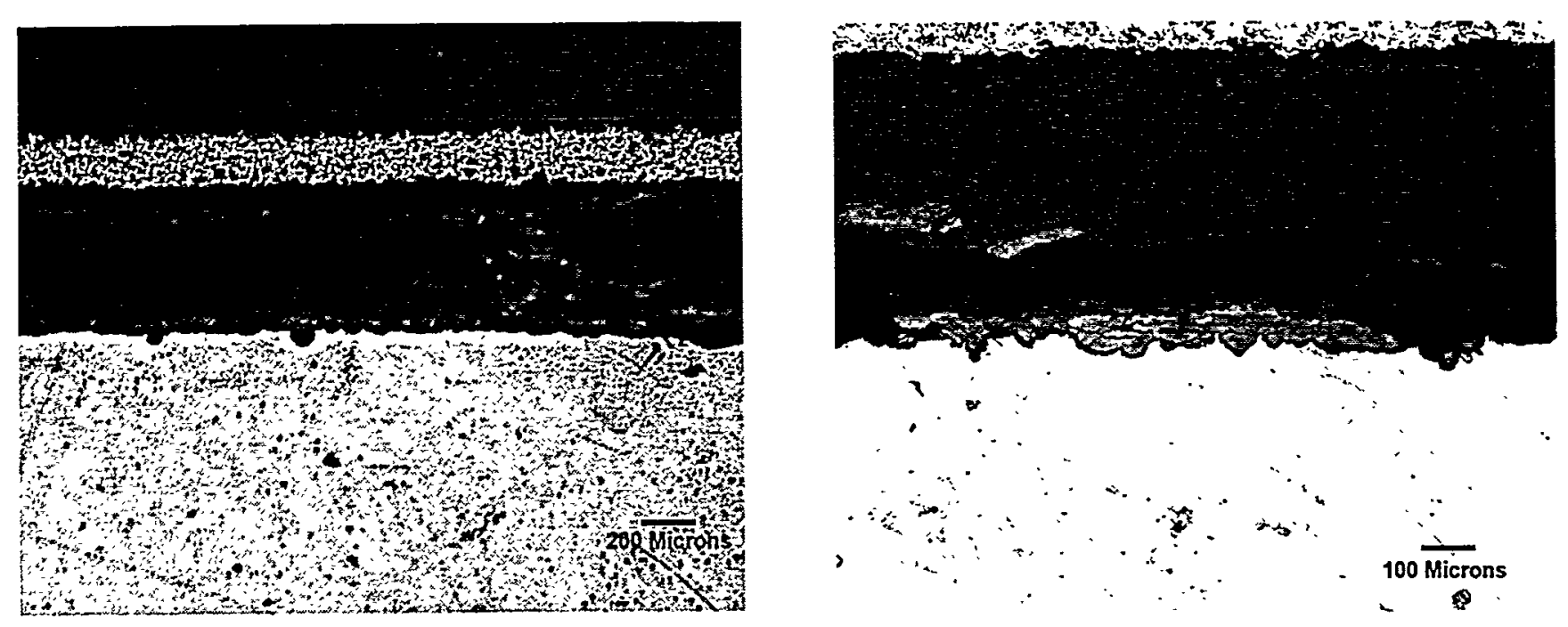

Figure 23. Cross sections of $\mathrm{NiCr}-\mathrm{Cr}_{3} \mathrm{C}_{2}$ coating and substrate after exposure (25 and $50 \mathrm{X}$ magnification).
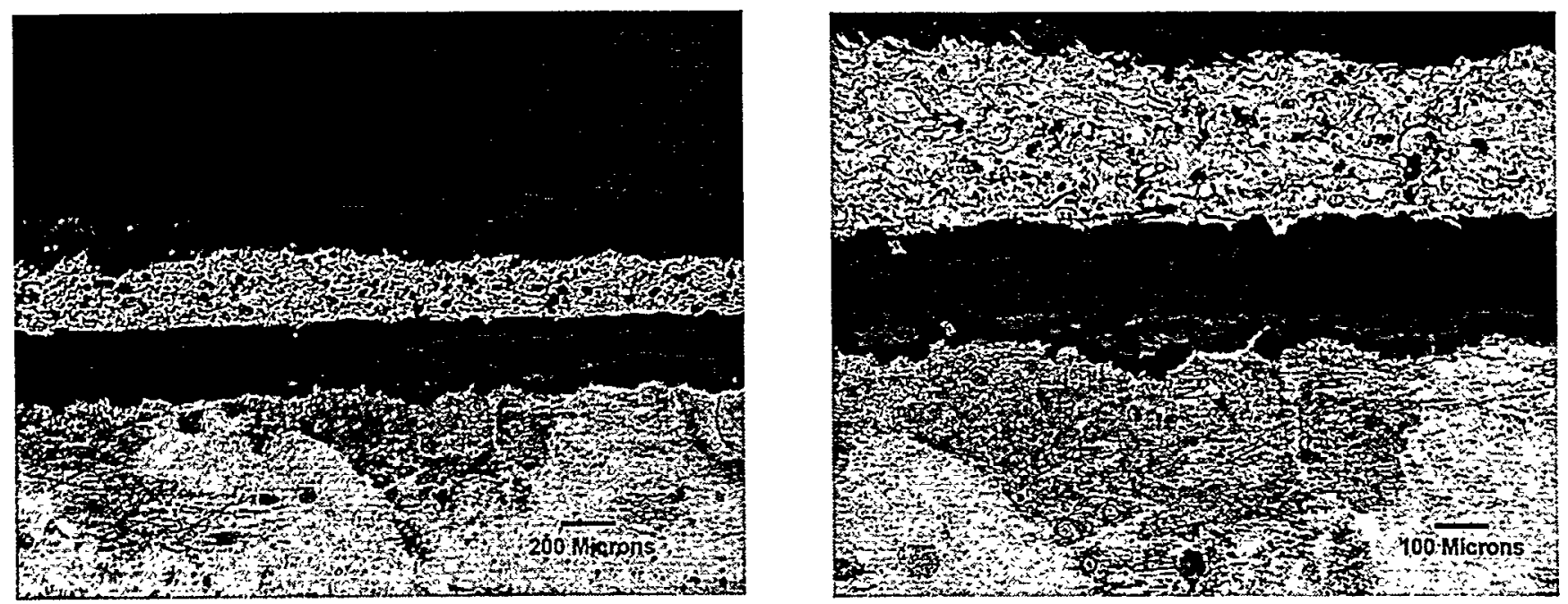

Figure 24. Cross sections of NiCoCrAlY coating and substrate after exposure (25 and 50X magnification). 


\subsection{Alternatives to Ni-Al Coatings}

Since the corrosion performance of Ni-Al appears less than optimal and there is concern about coupling an alloy coating to a barrier coating (the thermally conductive composites), alternative means of coating the tube ends should be considered. It would be preferable to use an ambient cured polymer with the appropriate durability in high temperature brine. Thermal sprayed polymers may also be suitable if they can be applied to the tube ends. In any case it is necessary to apply the end coating after roller expansion to prevent damage. This problem and possible alternatives are currently being discussed with coating manufacturers and commercial heat exchanger liner applicators.

\subsection{Conclusions}

Plasma spraying the internal diameter of 0.875 inch heat exchanger tubes with $\mathrm{Ni}-\mathrm{Al}$ can be achieved to a depth of about two inches with an extension nozzle. However, the coating thickness is variable and the surface is relatively rough. Furthermore, the coatings are porous. The four tested $\mathrm{Ni}-\mathrm{Al}$ coatings provided some corrosion protection to bare steel in hypersaline brine. Measured corrosion potentials indicated that the $\mathrm{Ni}$-Al coatings are active towards steel coated with thermally conductive polymers. This suggests preferential corrosion. Substrate corrosion occurred on Ni-Al coated coupons tested in a volcanic pool in New Zealand with similar chemistry to geothermal brine although this may have been associated with difficulties in achieving a uniform coating on the coupon edges. It is recommended that alternatives to $\mathrm{Ni}$ - $\mathrm{Al}$ for safe ending heat exchanger tubes be explored. Specifically, a durable and scale resistant polymer-based barrier coating that can be applied after roller expansion of the lined tubes is required. Another alternative would be to modify the current process for application of the thermally conductive composites so that the tubes can be lined in-situ after connection to the tubesheet.

\subsection{References}

M.L. Allan, C.C. Berndt and D. Otterson, Polymer Coatings for Corrosion Protection in Biochemical Treatment of Geothermal Residues, Geothermal Resources Council Transactions, Vol. 22, San Diego, 425-430, 1998.

J.Z. Chen, H. Herman and S. Safai, Evaluation of NiAl and NiAl-B Deposited by Vacuum Plasma Spray, Journal of Thermal Spray Technology, V. 2, No. 4, 357-361, 1993.

S.C. Deevi, V.K. Sikka, C.J. Swindeman and R.D. Seals, Reactive Spraying of Nickel-Aluminide Coatings, Journal of Thermal Spray Technology, V. 6, No. 3, 335-344, 1997.

A. Geibel, L. Froyen, L. Delaey and K.U. Leuven, Plasma Spray Forming: An Alternate Route for Manufacturing Free-Standing Components, Journal of Thermal Spray Technology, V. 5, No. 4, 419429, 1996. 